IZA DP No. 5776

Mandated Severance Pay and Firing Cost Distortions: A Critical Review of the Evidence

Donald O. Parsons

June 2011 


\title{
Mandated Severance Pay and Firing Cost Distortions: A Critical Review of the Evidence
}

\author{
Donald O. Parsons \\ George Washington University \\ and IZA
}

\section{Discussion Paper No. 5776 \\ June 2011}

\author{
IZA \\ P.O. Box 7240 \\ 53072 Bonn \\ Germany
}

Phone: +49-228-3894-0

Fax: +49-228-3894-180

E-mail: iza@iza.org

Any opinions expressed here are those of the author(s) and not those of IZA. Research published in this series may include views on policy, but the institute itself takes no institutional policy positions.

The Institute for the Study of Labor (IZA) in Bonn is a local and virtual international research center and a place of communication between science, politics and business. IZA is an independent nonprofit organization supported by Deutsche Post Foundation. The center is associated with the University of Bonn and offers a stimulating research environment through its international network, workshops and conferences, data service, project support, research visits and doctoral program. IZA engages in (i) original and internationally competitive research in all fields of labor economics, (ii) development of policy concepts, and (iii) dissemination of research results and concepts to the interested public.

IZA Discussion Papers often represent preliminary work and are circulated to encourage discussion. Citation of such a paper should account for its provisional character. A revised version may be available directly from the author. 


\section{ABSTRACT \\ Mandated Severance Pay and Firing Cost Distortions: A Critical Review of the Evidence*}

Severance pay mandates are an appealing job displacement insurance strategy in developing countries, which have only modest government administrative capacities, but they carry the threat of adverse indirect effects. A critical review of the empirical literature reveals that severance benefit mandates, unaccompanied by other labor regulations, have little apparent impact on labor market behaviors. Indeed many severance mandates in the industrialized world do not greatly exceed those provided voluntarily in larger firms in the U.S. Benefit mandates in the developing world are sometimes more extravagant, and the absence of substantial effects may result from limited enforcement. Broader economic regulations do appear to have substantial, adverse effects on the labor market, but it is important not to equate these with simple severance insurance plans.

JEL Classification: J08, J65, J33

Keywords: $\quad$ severance pay, firing costs, hiring costs, separation rate, employment

Corresponding author:

Donald O. Parsons

Economics Department

George Washington University

2115 G Street NW

Washington, DC 20052

USA

E-mail: dopars@gwu.edu

\footnotetext{
* The encouragement of Milan Vodopivec and the financial support of the World Bank were critical in launching this project, and the luxury of a sabbatical year at GW in its completion. Jacqueline Iwata generously provided research assistance. Robert Holzmann and two anonymous reviewers provided detailed comments. I would also like to acknowledge the comments of Bryan Boulier, Robert Goldfarb, Stephen Smith, and participants in the GWU microeconomics seminar and the World Bank's labor economics brown bag lunch.
} 


\section{Introduction}

Severance pay mandates have a special appeal in developing countries, which have only modest government administrative capacities for direct provision of job displacement insurance. Such mandates have been viewed warily by economists, however, with a concern that the implied "firing costs" might negatively affect the efficient allocation of labor across firms and industries. Robert Holzmann succinctly summarizes a number of major issues:

Severance pay is quite likely the most wide-spread benefit program for workers in the world.... These payments at the end of a work contract and in most cases of an involuntary separation can be found in almost all countries.... They are mostly mandated by law but result also from contractual commitments....[They] are often held responsible...[for] poor labor market performance in poor and rich countries alike and are therefore tackled as part of a reform agenda to improve the competitiveness of the national economy. Holzmann (2005, p.251)

Holzmann goes on to deplore that "...knowledge gaps apply to the effects of severance pay on labor market outcomes such as job creation and unemployment rate, the distributive effects between individuals and over time..." Holzmann (2005, p.252). In this paper I argue that the empirical literature is in fact highly informative on this issue once severance pay effects are separated from other, broader interventions--estimated effects are small.

Early work on this topic introduced an apparent paradox. Lazear (1990), in his seminal work on the topic, noted that such mandate effects could be avoided by a simple bonding scheme, but then interpreted his empirical work as indicating large, adverse effects. He conjectured that the paradox could be resolved by an appeal to pervasive worker credit constraints which would make avoidance costly. More recent work has only deepened the paradox, with the recognition that severance mandate effects can be avoid through variants of familiar, widely adopted mechanisms like private pensions, suggesting that avoidance costs may not be especially onerous, Parsons (2011a,b).

If avoidance costs are small but avoidance activities absent, it is natural to conjecture that the original distortions are small. The widespread provision of voluntary severance pay among private firms in the U.S. would seem to support that argument. Although voluntary severance benefits are often modest, they are equivalent to mandated levels in many OECD 
countries. Have the firing costs embedded in severance insurance mandates artificially reduced separation rates and perhaps depressed employment rates and increased unemployment levels? This review focuses on what we know about these connections, especially to turnover and equilibrium employment. ${ }^{1} \quad$ Another direct implication--that by "protecting" the jobs of current employees, severance pay mandates alter the distribution of jobs across demographic groups--also receives attention.

Early work by Emerson (1988) and especially Lazear (1990) stimulated intense interest in the topic, and encouraged a variety of estimation efforts. ${ }^{2} \quad$ Although a casual review of the empirical evidence might suggest otherwise, severance-induced firing costs do not appear to be a serious problem. To begin, employment protection legislation and even severance pay are complex instruments, with job displacement insurance only one element Moreover, severance benefit mandates are often a small part of more substantial policy reforms, many of which are themselves distortionary, making identification of the effects of individual elements difficult. The challenge is to isolate severance insurance effects from those of broader interventions.

The next section provides a brief review of key design features of severance pay as job displacement insurance plan. Much attention has focused on benefit generosity, but program "type," especially whether the plan is an insurance plan or savings plan or something in between, is also critically important, Parsons (2011a,b). After all, savings plans have no firing cost implications. Section III provides an informal theoretical discussion of firm avoidance strategies, adopting the standard flow approach, Nickell (1978) and Bertola (1992), and focusing on turnover rates and employment levels. ${ }^{3}$ Mandate avoidance is not technically difficult. Separating severance insurance effects from those of other

\footnotetext{
${ }^{1}$ Unemployment effects, the policy problem that energized much of this literature, is a more complex, institutionally specific process, Mincer (1976), and is not dealt with here. For a concrete illustration of the problem, see Blanchard and Portugal (2001). Of special note, I ignore here the important work by Layard, Nickell, and associates, for example Nickell and Layard (1999), that primarily focuses on unemployment processes.

${ }^{2}$ The analysis to follow, as any review of a large literature, must be somewhat idiosyncratic, and is far from all-inclusive.
} 
economic market reforms is crucial to the review below, and a taxonomy of reform types is presented in Section IV, with severance pay reform but one element.

The empirical review begins with a handful of prominent empirical studies. In Section V, Lazear's work, which has strongly influenced subsequent research, is highlighted. Lazear explored severance pay effects on employment and other labor market measures using a cross-national panel drawn from the industrialized world ("OECD"), admitting few controls and only one additional policy, advance notice. The boldness of the research design perhaps foreshadows the non-robustness of the results, Addison and Teixeira (2005).

The more recent analysis by Heckman and Pagés (2004) is the focus of Chapter VI. Their analysis expanded (i) the policy vector to include severance savings mandates and social security mandates, and (ii) the cross-national sample to include Latin America and Caribbean (LAC) countries as well as those in the OECD. The results provide little reason to be concerned about severance insurance mandates.

The logical extension of this approach, introducing a full array of policy characteristics. potentially into tens and even hundreds of policy dimensions, is not feasible. ${ }^{4}$ Moreover policies are often highly correlated in application, making estimation of individual effects imprecise. Work by the $\operatorname{OECD}(1999,2004,2006)$, which compressed a large number of policy elements into a single employment protection legislation index (EPL) illustrates an alternative approach, one that overcomes the problem of identifying individual policy effects by assumption-that all policy effects are identical, Section VII. Obviously this does not provide a reliable guide to the impact of any single policy.

Section VIII reviews a handful of other major cross-national and cross-state analyses of labor standards, including severance pay mandates, and their consequences. A prominent study of international "labor standards" by Botero, Djankov, La Porta, Lopez-deSilanes, and Schliefer (2004) focused on the origins of such regulations, but also looked at

\footnotetext{
3 Blanchard (1998) provides an accessible and oft cited discussion of this approach.

4 Some of the same difficulties arise in trying to identify individual policy determinants of "good governance," Kraay and Tawara (2010).
} 
the gains and losses of alternative regulatory regimes. ${ }^{5}$ The authors suggested that the benefits and, more important to us, the (distortionary) costs of such programs are rather small. Studies across Indian states by Besley and Burgess (2004) and refined and extended in important ways by Ahsan and Pagés (2008) hinted that other dimensions of labor standards, notably collective bargaining rules, may be more important than employment protection legislation in molding labor market performance.

The review then turns to quasi-experiments, beginning with whole-scale, economywide economic reforms, Section IX. These studies track the implications of simultaneous changes in capital, labor, and product market regulations as well as the easing or tightening of international trade restrictions. Two paradigm reforms receive special attention, the Columbian reforms circa 1990, Kuglar (1999, 2002, 2004, 2005), and the Peruvian reforms of the same time period, Saavedra and Torero (2004). Although interesting in their own right-providing strong evidence that substantial government interventions in the economy are likely to affect labor market performance adversely--such studies provide little practical guidance on the design of severance plan mandates.

The impact of less comprehensive legislation, especially of employment protection legislation (EPL), is then reviewed in Section $X$, beginning with its impact on job separation rates and redistribution, including recent studies by Micco and Pagés (2006) and Haltiwanger, Scarpetta, and Schweiger (2008). In Section XI, a set of studies designed to estimate EPL effects on "jobs," their aggregate number and their distribution across demographic groups, is assessed. The impact of labor market policies on the distribution of jobs across demographic groups emerges as perhaps the most robust finding in this literature.

\footnotetext{
5 The authors (2004, p.1340) find that "In broad terms, common and civil law traditions utilize different strategies for dealing with market failure: the former rely on contract, the latter on direct supervision of markets by the government." Obviously this observation is incomplete as a theory of labor regulation; it cannot for example explain regulatory change, including the many "reforms" that provide the bulk of the material for the empirical studies to follow. Nonetheless the finding provides mild support for the idea that the rules, including severance mandate, are not determined by the impact of the regulations, an idea implicitly embraced by most of the studies reviewed here.
} 
The finding that EPL does appear to reduce job separations and to redistribute jobs toward "prime age" adults has only the faintest of implications for severance pay designers. Once unbundled, is the impact of severance pay mandates similar? Section XII provides evidence of the converse; large changes in government dismissal policies that leave severance benefit generosity unaltered, have large effects on labor market outcomes, Marinescu (2009), while less substantial ones, for example, recent alterations in employment-at-will contracts in the U.S., do not. The number of studies that report the effects of variations in severance generosity on labor market performance is surprisingly small; that said, the studies provide little reason for serious concerns, at least at generosity levels typically observed in the industrialized world, Section XIII. XIV concludes.

\section{Severance as Job Displacement Insurance: An Overview}

A variety of severance plan characteristics are important in the discussion to follow, including:

- Plan type: insurance, savings, or some mixture (eligibility requirements for benefit status);

- Benefit schedules; and

- Enforcement procedures for regulations.

These key elements are briefly reviewed In the remainder of this section.

Benefit eligibility. A key element of any severance plan is the conditions under which benefit payouts are made to the worker. Two polar plan types of severance plan are common-insurance and savings:

Severance (insurance) pay. Separation payments in excess of accrued wages, vacations, and accrued leave that are paid out if the worker is involuntarily separated from his job (without worker malfeasance). ${ }^{6}$

Severance (savings) pay. Accrued benefits are ultimately distributed to the worker, though the timing of disbursement is restricted to job separation of some sort, including retirement.

Severance plans that include the right to borrow under certain contingencies-schooling, house purchase, starting a business-imply the funds will ultimately accrue to the worker and are savings plans. This distinction is fundamental because severance savings pay

${ }^{6}$ These are often labeled redundancies. 
ordinarily carries no firing cost implications. Unless the savings accrual formula is seriously at variance with market discount rates, the firm is indifferent between cashing out the worker's savings account now or later. ${ }^{7}$ Indeed the firm may not even hold the worker's savings; savings mandates may specify that financial intermediaries or government agencies hold the funds.

Severance insurance plans and severance savings plans can be viewed as polar cases of a continuum of eligibility requirements, with the traditional severance insurance plan limiting benefit eligibility to involuntary separation and savings plans paying out under all separation circumstances, Parsons $(2011 a, b)$. A severance plan that pays out benefits across the universe of job separation reasons, including retirement, is effectively a savings plan.

Holzmann, Pouget, Weber, and Vodopivec (2011, Table A1) present information on benefit eligibility requirements for a broad sample of countries that can be used to fashion a sense of the popularity of the insurance and savings forms of severance pay, with their quite different implications for firing costs. They systematically canvassed 113 countries and reported that fully one hundred (100) or 88 percent had some form of national mandated severance plan. A number of the remainder had severance pay provisions in union contracts, which may be more important in say Belgium, a nation with no government mandate, than in the U.S. with its limited union coverage.

Of the 100 countries, two were simply savings plans, Italy and Peru, while others spanned the range of benefit-eligible separation events. A small number (4) were sufficiently exotic that they did not cover redundancy (involuntary economic separations), or bankruptcies, and defy categorization. ${ }^{8}$ The remainder can be broken out into three broad groups: (i) redundancy and bankruptcies only (18); (ii) redundancies and dismissals or

\footnotetext{
${ }^{7}$ Because benefits are typically determined as a fraction of weekly or monthly wages, expected wage inflation is also a critical issue if wages are not stable. In that case neutrality would require both wage inflation and discount factor adjustments.
} 
separation with cause (54); and (iii) broader eligibility requirements, including redundancies, dismissals, plus voluntary separations and/or old age retirement (24).

The latter group provided a variety of alternative separation coverage policies. Fourteen (14) covered voluntary separations, but not retirement. Four (4) covered retirement, but not voluntary separation, ${ }^{9}$ and six (6) mandated severance plans with sufficiently broad eligibility requirements that they are effectively severance savings plans. ${ }^{10}$

Benefit Schedules. There are two key aspects to the benefit schedule, individual (the payout to an individual worker) and the aggregate (the total expected payout to workers for a given employment reduction). In the voluntary U.S. economy, coverage varies widely by occupation and industry, Bishow and Parsons (2004), but the basic benefit schedule is reasonably uniform, Parsons (2005). For those eligible, benefits are offered at the time of involuntary displacement in proportion to the worker's weekly wage and years of service with the firm, often up to a benefit or years-of-service maximum. Especially for blue collar and service workers and clerical workers, the modal plan offers one week of pay per year of service, Parsons (2005).

The one-week-of-pay-per-year-of-service rule is also a feature of many mandated international plans. Figure 1 presents mandated benefit levels by occupational group (blue collar, white collar) at 20 years of service for OECD countries. If the U.S. median benefit level of one week per year of service is used as a measure of the level of voluntary plans, many mandates may not be effective in the sense of binding on the firms.

It is also important to recall that firms have considerable leeway in choosing who to displace and may never have to pay severance benefits to a specific worker. Although large severance liabilities may accumulate among the longest tenured workers, these are cancelled when the worker retires under severance insurance plans, though of course not

8 These four are Armenia, Israel, North Korea, and Uganda. Incapacity separation is a simple form of disability insurance, and can be found in all four of these and in combination with redundancy and other separations in about 20 percent of the remaining 96 countries.

9 Pre-reform (2003) Austria provides an example of such a program. Benefits were paid out for involuntary layoffs and retirement, but not for voluntary separations (quits). 
under severance savings plans. As a consequence the individual benefit schedule is only one factor in the firm's total expenditures and related firing costs. At any point in time, the firm faces a workforce with varying service records, and may be free to choose which worker it will lay off. ${ }^{11}$ Aggregate severance payouts will be minimized for a given force reduction under the common LIFO (last in first out) layoff strategy. Severance benefit costs grow at an increasing rate with the depths of the employment cuts, but in ordinary times firms can manage layoffs in a way that limits aggregate severance benefit payouts to modest levels. Indeed Pagés and Montenegro (2007) argue that severance mandates will induce firms to use LIFO, even if they otherwise would not, to the disadvantage of the young.

Enforcement. Mandating a specific severance plan that the firm would otherwise not choose to offer requires an enforcement mechanism if it is to be effective. Severance pay mandates differ substantially and importantly in bureaucratic demands. If, as is typical in severance insurance plans, benefit eligibility is restricted to involuntary separations or layoffs-the structure of dispute resolution is important. Which party must prove its case in a dispute? A number of studies discussed below use enforcement likelihood as a means of identifying mandating effects. To my knowledge, no study uses direct measures of compliance with severance legislation. ${ }^{12}$ Instead one is likely to see measures of social insurance compliance, or even general measures of the lawfulness of the population.

The Second Face of Dismissal Regulations. Bureaucratic demands for severance pay administration merge into broader "dismissal" regulations, including requirements of government or union approval of separations or even prohibition of dismissal. In an early study, Emerson (1988) cites European employer surveys that emphasize the importance of these noncash firing costs; employers confronted with unusually high severance benefit

\footnotetext{
${ }^{10}$ Two of these, Italy and Peru were simply severance savings plans.

11 For discussions, see Pagés and Montenegro (2007) and Goerke (2006).

12 See however the interesting work by Almeida and Carneiro (2009), which exploits variations in labor inspection visits per firm across localities in Brazil to estimate the impact on firm size. Ceteris paribus, firms in cities with more intense inspection schedules are smaller in a variety of dimensions, presumably to reduce the likelihood of inspection.
} 
mandates were inclined to report serious firing impediments, but the converse was not necessarily true.

Of special note, involuntary separations can arise for disciplinary reasons, as well as economic ones. Although the focus of this review is on severance as job displacement insurance, dismissal regulations often serve a quite distinct function, reducing the employer's control of workplace discipline. ${ }^{13}$ Almost omnipresent in labor union contracts in the United States is the designation of grievance processes--mechanisms designed to regulate the interactions between worker and management, including the resolution of disputes over dismissal for disciplinary reasons, commonly referred to as discharges or fires. Government regulations can and do extend such regulations to the general workplace under the requirement that the employer be penalized for releasing workers without "just cause."

It is important to disentangle, if possible, workplace control regulations from consumption smoothing regulations. There is no reason to assume that regulation of separations for economic reasons-implicit in the insurance perspective-should have the same effect as regulation of disciplinary separations. The regulation of discharge separations, including the total banning of such separations, is not likely to have a large, direct impact on aggregate separations, but it is likely to affect workplace efficiency and therefore separations, accessions, and equilibrium employment if not offset with wage adjustments. $^{14}$

\section{Severance Policies and Outcomes: Some Theoretical Structure}

Severance policies may affect a range of economic processes. The review to follow focuses on the following outcomes:

- Job Turnover (Separations and Accessions); and

- Employment;

- Employment Redistribution

\footnotetext{
${ }^{13}$ Holzmann, Pouget, Weber, and Vodopivec (2011) report that severance insurance mandates in the vast bulk of countries (54 of 72 or $75 \%$ ) include dismissal as well as redundancy as benefit qualifying separation events.

14 See Parsons (1986), Malcomson (1999), and Salanié (2005) for reviews of the contract literature.
} 
Obviously each of the outcomes must be measured with reasonable accuracy, although, most countries have developed some capacity for this.

Because severance pay mandates can be viewed as a penalty for job separations, a flow approach is used to organize the analyses to follow. The basic decision mechanism emphasizes worker flows (separations and accessions) with employment stock as an important but indirect outcome. ${ }^{15}$ Elegant recent studies have emphasized the dynamics of the process and adjustment costs, but the core principles are sufficient here. Major elements of the flow processes are revealed in the flow model identity:

$$
E_{t} \equiv E_{t-1}+A C C_{t}-S E P_{t}
$$

or equivalently:

$$
\Delta E_{t} \equiv E_{t}-E_{t-1}=A C C_{t}-S E P_{t}
$$

where

$E_{t} \equiv$ employment at the end of period $\boldsymbol{t}$,

$\boldsymbol{A C C _ { t }}$ =accessions or hires in period $\boldsymbol{t}$, and

$S E P_{t} \equiv$ separations in period $t$,

Firing costs. The direct effect of a severance insurance mandate (firing costs) on separations $\left(\mathbf{S E P} \boldsymbol{P}_{t}\right)$ is likely to be a negative one, although perhaps smaller than severance benefits alone might suggest, Parsons $(2011 a, b)$. For planning purposes, the net cost of a severance benefit payout must be adjusted by any reduction (or increase) in future liabilities. ${ }^{16}$ It is for that reason that severance savings accounts have no firing costs; a future liability is reduced dollar-for-dollar with the payout (assuming some reasonable accrual of interest.)

A reduction in separations will have an immediate but opposite effect on accessions, unless the firm wishes to alter the size of its workforce. If separations and accessions occur

15 Nickell (1978) and Bertola (1992) provide clear introductions to the underlying employment dynamics in a world of certainty. Bentolila and Bertola (1990) and Bertola (1990) introduce uncertainty. Bertola (1999) provides a review, Blanchard (1998) an accessible discussion.

16 This argument is developed informally, with a variety of examples, in Parsons (2011a). Parsons (2011b) provides a formal statement of the argument. 
at different points in the business cycle, severance pay would presumably limit separations during bad times and accessions during good. ${ }^{17}$

Hiring Costs. Mandated severance benefits enter the equilibrium employment decisions through hiring costs, not firing costs. Gross hiring costs-the firm's perception of the expected expenditures under the mandate-will include, in the first instance, the sum of discounted expenditures mandated under the regulation (or the cost of avoiding these same regulations, whichever is less). The worker's valuation of the mandated benefit is also important if wages are downwardly flexible. Net hiring costs of a mandate could be zero, or even negative, if the firm is supplying a product the worker values and cannot obtain elsewhere. $^{18}$

The firm has a variety of institutional and contractual means of avoiding a mandate, often with quite different firing cost and hiring cost limplications. The firm can ease into the informal sector, which is rather easily done in the developing world if the firm is not large; it can spin off self-employed workers; or, if law permits, it can hire more temporary workers. Lazear (1990) highlighted the possibility of contractual avoidance behavior. A severance insurance mandate can be "undone" by (i) paying out additional benefits to employed and terminated alike and (ii) recapturing the cost through compensating wage differentials. The firing costs can equivalently be undone with smaller outlays by promising to pay out benefits only at the time of separation, but doing so for separations of all types, involuntary or voluntary or through retirement, Parsons $(2011 a, b)$. This approach converts the insurance plan into a severance savings plan, essentially a defined contribution pension plan. Clearly private pensions are common in many economies so it seems plausible that the conditions for such an offset are not especially demanding.

17 See Hunt (2000) for an interesting empirical application.

18 Relatively common voluntary severance plans in the U.S. suggest that this is not wholly fanciful, although voluntary plans in the U.S. are less generous than are many mandated plans elsewhere, and more tightly targeted on white collar workers in volatile industries, Parsons (2005) and Bishow and Parsons (2004) respectively. 
The firm can undo a mandated severance insurance plan simply by offering a "cliffvested" pension plan, which is to say a pension plan that pays benefits only if the worker remained with the firm until normal retirement age. ${ }^{19}$ Note that such an integrated severance insurance/cliff-vested pension plan requires a greater outlay by the firm (higher gross hiring costs) than severance insurance alone. Whether net hiring costs are increased depends on the worker's access to capital. If the worker has access to capital at the same interest rate as the firm, the worker might well value the pension plan at cost and net hiring costs might be zero. As with the bonding mechanism of Lazear, pension/savings plans become less attractive as worker discount rates grow.

There is no empirical evidence of contractual avoidance behavior, despite its apparent ease. Indeed there is contrary evidence for the U.S. As noted above, firms in the U.S. frequently adopt voluntary severance plans, and these are invariably insurance plans, not savings plans. Moreover few OECD countries mandate severance savings plans, though presumably they could. The Korean severance system is a savings plan, as is the Austrian plan after the 2003 reforms. $^{20}$ In Latin America and the Caribbean, severance insurance plans and severance savings plans may be mandated simultaneously, Heckman and Pagés (2004).

That voluntary plans in the U.S. are typically severance insurance plans, and that OECD governments typically mandate severance insurance plans, not severance savings plans are both consistent with the possibility that firms do not view the mandates as costly. This leads to the working hypothesis of this paper, that severance insurance mandates at benefit generosity levels normally observed in the OECD are not seriously distortionary.

19 Such plans were once common in the U.S. but are now illegal under ERISA, which mandates rapid vesting of pensions.

20 Prior to 2003, the Austrian plan could be considered a "ninety percent savings plan, with payouts for involuntary job separation and retirement, but not for voluntary separations (quits). See Parsons (2011a). 


\section{Government Reforms: A Policy Taxonomy}

The severance-induced firing cost literature will be critically reviewed below, with special attention to research that appears to uncover substantial severance pay distortions. A problem arises immediately that "reforms" that include increasing or decreasing severance generosity often include other, sterner measures. Data from the IFC Cost of Doing Business (2009) illustrates the strong correlation of business and labor market standards imposed by governments worldwide. Figure 2A, for example, illustrated the linkage of hiring and hours usage regulations with termination regulations across selected countries. The prevalence of these three types of labor regulations is presented for the ten (10) highest ranked and the ten (10) lowest ranked countries in the sample of 182 countries. Countries with relatively flexible termination rules also have relatively relaxed hiring and hours adjustment rules, and vice versa. The same concern applies to general anti-business regulations, of which labor regulations are but one, Figure $2 \mathrm{~B}$. It would be difficult to isolate the effect of a single policy; the same firms that face significant labor market rigidities face a wide set of concerns about business startup and closure and operations in between. Moreover reforms often bundle a variety of these measures.

It is important to separate severance pay effects from those of a wide range of alternative government interventions in product and factor markets. In descending order of policy expansiveness, we can identify these initiatives as:

- Economic Regulations (ER). Economic regulations refer to the full set of economic policies. ER would include product market, tariff and international trade, and capital market regulations as well as labor regulations (LR).

- Labor Regulations (LR). Labor regulations refer to the full range of labor market policies, including collective bargaining rules (CB) and labor standards (LS) such as hours regulations and minimum wages as well as EPL. The OECD (2004) notes that direct legislation of labor standards is only one way to transfer power to workers, collective bargaining rules are quite another. ${ }^{21}$ Unions are very much an invention of governments, and the powers governments bestow on them vary greatly. Even when focusing on separation costs, it matters little if the government directly imposes separation regulations or empowers union representatives to do that for them.

21 Grubb and Wells (1993) give a clear account of the interplay of pro-worker collective bargaining rules and direct severance mandates. 
- Employment Protection Legislation (EPL). A proper subset of labor standards, EPL refers to regulations of worker separations. A requirement that firms receive government approval for job separations is a dismissal regulation that is not, directly at least, a severance generosity mandate. A pronouncement that job separations are illegal is another, extreme example. OECD (2004) notes three distinct separation cost elements: (i) the difficulty of dismissal; (ii) "procedural inconveniences" that may follow implementation of the dismissal; and (iii) any advance notice costs or severance pay that may be required.

- Severance Pay (SP). Severance pay regulations refer specifically to government rules on the provision of job separation pay. Severance pay is itself multidimensional, with benefit generosity only one dimension of a potentially complex mechanism. If benefits are limited to a class of job separations, say those that cannot be "economically justified," it becomes important to know whether the worker or the employer has the burden of proving the employer's initial classification incorrect.

As a general rule, the more focused the policy reform under review, the more informative the analysis for severance pay design.

\section{An Early Cross-National Study: A Bold Empirical Adventure}

Although researchers have long been well aware of the many dimensions of severance pay, for example Emerson (1988), early research focused on benefit generosity. In his seminal study, Lazear (1990, pp.707-708) constructed a severance pay measure (SEV) as: "the number of months of severance pay or notice a blue collar worker with ten years of service received upon termination without "cause'”. He also experimented with a second dismissal policy measure, advance notice.

Lazear reported estimates from a variety of models, but focused his discussion on OLS estimates of a cross-national model of "22 developed countries over 29 years" (p.699). He proposed to model the employment-to-population rate $(E / P)$, unemployment rate, labor force participation rate and average work hours as a function of a severance pay measure and year and year square. For example, suppressing individual subscripts:

$$
E / P=\alpha_{0}+\alpha_{1} S E V+\alpha_{2} T+\alpha_{3} T^{2}+\varepsilon
$$

with $\boldsymbol{T}$ denoting a year index, and $\boldsymbol{\varepsilon}$ the random element.

Few economists would a priori write down such a model for the aggregate employment-to-population ratio. More astonishing--perhaps even to Lazear--if the country observations are simply pooled, the estimated SEV coefficients in three of the four labor 
market outcome models are negative and statistically significant, with the unemployment rate effect also significant, though positive, Lazear (1990, Table II, p.712). If a second policy variable (notice) is introduced as an explanatory variable, however, all SEV coefficient estimates are sharply less significant, with the estimated impact on unemployment now negative but insignificant.

Given the stability of job dismissal policies within countries across time, it is perhaps not surprising that the results are not robust to the addition of country dummies. In the fixed effects model with only severance pay as an explanatory variable, the employment and labor force participation coefficients are not significant at customary levels (Table $\vee$ p.714). Unfortunately Lazear reported only the OLS version of a model with additional explanatory variables. $^{22}$

Lazear (1990, p.725) ended his paper with the hope that “...these initial estimates provide a departure point for more refined models and data", and indeed the study stimulated an explosion of variable measurement, model extensions and replications. Addison and Teixeira (2003) provide an exceptional review of their own work and that of others that followed Lazear's study, drawing the following conclusions:

1. “...annual rates of job reallocation (i.e. job flows) are often as high in nations with stringent job protection as in countries with weak regulation. This awkward empirical regularity has prompted some ingenious explanations..." (p.121).

2. "...Employment is reduced on net," (p.120), though the effects are not uniform across demographic groups-prime age males are unaffected, but the young are; and

3. “...the coefficient estimates for employment protection equations in overall unemployment are of mixed sign" (p.121)

The need for explanation of result (1) is obvious--it strikes at the core of the firing cost concern. ${ }^{23}$ If firing costs do not reduce job separation rates, how important can firing costs

\footnotetext{
22 In a detailed analysis of the Lazear models, Addison, Teixeira, and Grosso (2000) did report estimates of the fixed effects model with the additional covariates and report that the severance pay index coefficients were insignificant for both the employment rate and the unemployment rate, but positive and significant for labor force participation and hours (Table 3, p.114). Correcting for first order autocorrelation leaves none of the SEV coefficients significant (Table 4, P.115).

${ }_{23}$ This observation is not inconsistent with simple theory if the economy has two sectors, with only one covered by the severance mandate.
} 
be $?^{24}$ Fortunately for the simple theory and common sense, the first proposition has been largely overturned in more recent work.

\section{Extending the Dismissal Policy Vector: Heckman Pagés}

As part of an ambitious project that extended the OECD sample to Latin America and the Caribbean (LAC) countries, Heckman and Pagés (2004) undertook a cross-national panel study that deepened the Lazear model in a variety of important ways. Their estimates were derived from an unbalanced panel of OECD and LAC (Latin American and Caribbean) countries over the period 1983 to 1999 . The broader sample introduced more policy variations and permitted them to estimate the effects of a vector of capitalized termination benefits composed of:

- Indemnity for dismissal (severance insurance pay);

- seniority pay (severance savings);

- social security payroll taxes, and

- advance notice. ${ }^{25}$

Of special note, Heckman and Pagés clearly distinguished between severance insurance mandates and severance savings mandates.

Their severance insurance (dismissal indemnity) measure can be viewed as a probabilistic weighting of benefits, namely:

"the discounted costs of future indemnities [measured in monthly wages], weighted by the probability of dismissal after i periods at the firm." Heckman and Pagés (2004,p.27).

This is a gross hiring cost measure of the severance mandate, Parsons (2011b). ${ }^{26}$ All measures reflect the discounted cost of the programs at the time of hire, unadjusted for equilibrium wage responses. Note that the gross hiring costs of (firing-cost free) savings plans are always higher than those of insurance plans, given the same benefit generosity. It is therefore important to treat the two mandates separately, which again Heckman and Pagés do

\footnotetext{
24 Hiring costs of course remain an issue, even if firing costs are zero.

25 Although the volume editors, Heckman and Pagés, and various authors of the individual papers clearly stated the importance of distinguishing payroll tax effects, as one might expect for savings mandates, and firing cost effects for severance insurance mandates, some volume authors were less careful to distinguish the two.

${ }^{26}$ As a practical issue, Heckman and Pagés (2004, p.80) report that using the Lazear measure and their own "yields similar results."
} 
Heckman and Pagés reported average cost figures for the various policies, which provide some perspective on the potential distortions that severance insurance mandates might impose. The gross hiring cost estimates (in multiples of monthly wages) of the four policies are reported in Table 1. As Heckman and Pagés (2004, p.31) note, "In the average Latin American country, social security payments amount to 82 percent of the total costs of labor laws. This percentage is even larger in OECD countries where, on average, they reach 96 percent of the total regulatory costs." It would be an unfortunate policy indeed if severance insurance pay, at 2 percent of expected labor law costs (OECD) and 8 percent in the Latin American countries (LAC), were to have profound negative effects on the performance of the labor market and the economy, although that remains an empirical possibility.

The empirical models are reduced form, fixed effects models of employment and unemployment regressed on the four labor mandates as well as various GDP and demographic regressors. A sense of the results can be obtained from the policy parameter estimates in the employment-to-population rate model reported in Table 2, based on results reported in Heckman and Pagés (2004, Table 8, p.72). The results are not especially intuitive. In the full sample, the severance insurance measure has a positive effect on employment, but neither it nor the advance notice coefficient is significantly different from zero at customary levels. When the model is estimated separately on the OECD sample and the LAC sample, the indemnity (severance insurance) effect in the OECD sample is negative and significant, while that in the LAC sample remains positive and insignificant.

The impact of severance savings mandates is, surprisingly, positive and significant. The circumstances under which a mandated severance savings plan would increase employment rates are not easy to imagine. Perhaps if the economy has no other savings mechanism, the firm may find it profitable to provide the service, though the government need not mandate the practice in that circumstance. 
Oddly the coefficient on the second compulsory savings contribution, to the government social security fund, is negative and significant. The authors provided the following conjecture on this reversal of sign:

Interestingly, we are able to reject the hypothesis that social security payments exert the same effect on employment as seniority pay [mandated severance savings], despite the fact that both variables imply mandatory contributions defined as a fraction of wages. Perhaps because the contributions to finance seniority pay are capitalized in individual accounts, the link between contributions and payments is strengthened, and this reduces or eliminates the "tax" effect. Instead, our results suggest that social security contributions tend to be perceived as taxes on labor.... Heckman and Pagés (2004, p.75).

Heckman and Pagés summarized their estimates thusly:

Unfortunately, few empirical regularities emerge when an honest sensitivity analysis is conducted. Nonetheless, a few robust regularities do appear. Payroll taxes reduce employment and (less robustly) in OECD countries job security regulation reduces employment. Heckman and Pagés (2004. p.65)

Heckman and Pagés do not directly estimate job redistribution effects, but summarized the studies, mostly microdata studies, in the volume, "Regulations act unevenly across different groups in society. Young, uneducated, and rural workers are much less likely to enjoy coverage than older, skilled, and urban workers," Heckman and Pagés (2004, p.70). More on this issue follows.

\section{Employment Protection Legislation: OECD Studies}

The four labor policies highlighted by Heckman and Pagés-advance notice, serverance insurance, severance saving, and social security contributions-are only a small set of potential policies, each of which has a large number of program parameters. Obviously multicollinearity concerns emerge as the number of policy instruments expands. Addison and Teixeira (2003) noted one especially important development in the post-Lazear literature, that more detailed measures are accommodated, not by expanding the vector of policy parameters in the analysis, but by constructing a composite employment protection measure. Grubb and Wells (1993), for example, stressed the multidimensionality of employment protection legislation, picking up on an earlier theme by Emerson (1988). They proposed combining a severance measure with an advance notice measure, weighting a 
month of mandated advance notice at 0.75 of a month of severance, ${ }^{27}$ and provided separate composite indicators for "regular procedural inconveniences" and "difficulty of dismissal." (pp. 12-14). These indices were themselves summed to create a composite strictness measure.

OECD (2004) extended the indicator approach, creating an elaborate employment protection legislation index involving eighteen component elements, Table 3 . Three of these measure, comprising less than 8 percent of the index weight, were severance generosity at various service levels:

- Severance payouts (in monthly wages) at 9 months tenure, at 4 years, and at 20 years. OECD (2004, p.103)

The three elements capture to some degree nonlinearities in the benefit schedule, though no attempt was made to estimate the independent impact of the three measures.

Advance notice mandates are included in the composite index as are measures that characterize limits on employer control of job discipline discharges, OECD (2004, pp.103105). Many OECD countries responded in the 1980 s to concerns that mandated severance charges were inducing high unemployment rates by introducing temporary contracts less burdened with job protection regulations. A complete description of the current severance pay environment would necessarily include a vector of permanent contract separation pay characteristics, a similar vector for temporary contracts, and a third vector that connects the two--the conditions under which the firm can choose between the two contracts. Aspects of these are also included in the OECD indicator.

The composite index is not useful in isolating severance pay effects unless the underlying assumptions implied in the index weighting are valid, which is unknown. The resulting studies do, however, provide a broad picture of employment protection legislation and its impact on labor markets in developed economies, OECD $(1999,2004,2006)$. The sample is, unfortunately, fairly homogeneous-few OECD countries mandate extravagantly Advance notice introduces special difficulties for hiring costs measurement. The maximum
possible outlay is the corresponding severance payout, which is the typical remedy for noncompliance 
high severance benefits. Offsetting that weakness, of course, is the likelihood that the underlying unobserved institutional structures are relative homogeneous, and that the laws are likely to be enforced.

The OECD (1999) labor market findings give a sense of the result of this approach. Among the highlighted results, largely derived from simple correlations and random effects GLS, are:

1. Stricter EPL is associated with lower turnover... with both jobs and unemployment spells tending to last longer." (p.50)

2. The employment-to-population ratio for the working age population tends to be lower in countries with stricter EPL, but this pattern reverses for prime-age men..." (p.50)

3. “...EPL has little or no effect on overall unemployment, but may affect its demographic composition. In countries where EPL is stricter, unemployment tends to be lower for prime-age men but higher for other groups, especially young workers." (p.50)

Perhaps reflecting the short (5-year) interval between the 1999 and 2004 studies, results (1) through (3) differ little in 2004. The negative employment effect of EPL, (2. above), appears especially robust for prime-age women and youth, and less so for older workers and low skilled workers, OECD (2004, p.85).

The 2004 OECD study, which focused more intensively on temporary contracts, added:

4. "Differences in the strictness of EPL for regular and temporary jobs may be an important element in explaining the rise in the incidence of temporary work for youth and the low skilled (this is less the case for other groups, notably primeage men.)" OECD (2004, p.63).

Of interest, they noted that the rigor of EPL across contract type (permanent, temporary) is positively and significantly correlated, OECD (2004, p.72), which they attributed to government concerns that a broad discrepancy in rigor between permanent and temporary contracts would induce a large flow toward the more flexible form. ${ }^{28}$

with a notice period, but the cost could be zero if the firm (i) complies with the regulation and (ii) does not experience a reduction in worker productivity during the compliance period.

${ }^{28}$ Conversely Booth, Dolado, and Frank (2002) argued that the fraction of the workforce in temporary contracts depends solely on EPL of regular contracts, not in any way on the EPL of temporary contracts. If true, this would be theoretically puzzling. 


\section{Labor Standards and their Consequences}

Before leaving the discussion of cross-national studies, two strands of literature provide some interesting speculations on government interventions in the labor markets, including its motivations and consequences. An ambitious study by Botero, Djankov, La Porta, Lopez-de-Silanes, and Schliefer (2004) examined the causes and effects of a broad range of labor market interventions, and did so over a yet wider sample of countries, though one must accept a corresponding reduction in average data quality. For a sample of 85 countries as of 1997 , the authors (i) created a broad index of the rigidity of "worker protection laws;" (ii) characterized the forces that make labor markets more rigid; and then (iii) mapped the resulting indices into measures of labor market performance.

The labor market performance measures were a little unusual-employment in the "unofficial economy," male and female labor force participation, and various unemployment measures. As for the labor standards measure, the one of special interest here is the worker protection index, which included measures of

$$
\begin{aligned}
& \text { - } \quad \text { collective bargaining law, } \\
& \text { - } \quad \text { emplocial security law, and } \\
& \text { - emplont law. }
\end{aligned}
$$

The employment law index is itself an average of indices for (i) alternative employment contracts, (ii) cost of increasing worker hours, (iii) cost of firing workers (the monetary cost of dismissal), and (iv) dismissal procedures (administrative costs of dismissal). Even the index of the cost of firing workers is a complex construction. Botero et al defined the monetary cost of dismissal as:

"Measures the cost of firing 20 percent of the firm's workers (10 percent for redundancy and 10 percent without cause). The cost of firing a worker is calculated as the sum of the notice period, severance pay, and any mandatory penalties established by law or mandatory collective agreements for a worker with three years of tenure with the firm. If dismissal is illegal, we set the cost of firing equal to the annual wage. The new wage bill incorporates the normal wage of the remaining workers and the cost of firing workers. The cost of firing workers is computed as the ratio of the new wage bill to the old." (Botero et al 2004, Table 1, P.1348).

Turning to the analysis, the authors had a special interest in the legal origins of the state interventions in the labor market (economic controls are limited to the log of GDP per capita), and they found (Botero et al 2004, Table IV, p.1366) as they conjectured, that legal 
origins mattered. More surprising, perhaps, is the finding that aggregate income did not affect the employment law index or any of its subcomponents.

The outcome models (unofficial employment, unemployment, labor force participation) are as spare as Lazear's, with the employment law index, the collective bargaining laws index, and the social security law index each entered in separate models, and with average years of schooling as the sole control variable. The four indices are presumably entered individually because of multicollinearity problems; theory does not suggest that only one can affect outcomes.

The various findings are difficult to summarize. The authors themselves reported that, "The strength of results varies across specifications, but in general they show no benefits, and some costs of labor regulation." Botero et al (2004, 1376-77). Looking a little more closely at the results, the employment law index, the index within which firing costs are embedded, had:

(i) an insignificant coefficient in the unofficial employment model,

(ii) a negative, significant coefficient in the male labor force participation model, and

(iii) positive, significant coefficients in various unemployment models,

Botero et al (Table VIII, 1376-77).

Conclusions (ii) and (iii) together suggest that formal employment is depressed by more vigorous employment laws, though this conclusion is of unknown statistical significance. The collective bargaining index increased activity in the unofficial sector, while, somewhat surprisingly, decreasing the labor force participation of men and increasing that of women. In contrast to the findings of Heckman and Pagés, the social security index was insignificant in all outcome models.

Caballero, Cowan, Engel, and Micco (2004) used the same data to shed light on employment security effects on labor market flexibility. For sixty countries over the period 1980-2000, they merged employment protection data from an earlier version of the Botero et al paper with "rule of law" measures from Kaufmann, Kraay, and Lozoido-Lobaton (1999) and employment-by-industry sector data from UNIDO (2002). They estimated the impact of EPL on employment adjustment speed. 
Although dynamic estimates of this sort tend to be highly model-dependent, the results were intuitive and compelling. They found that "Moving from the $20^{\text {th }}$ to the $80^{\text {th }}$ percentile in job security, in countries with strong rule of law [Greece or better], cuts the annual speed of adjustment to shocks by a third.... The same movement has negligible effects in countries with weak rule of law," Caballero et al (2004. Abstract). The economic security indicator is the sum of zero-one indices for four measures: (i) grounds for dismissal, (ii) dismissal procedures, (iii) notice and severance pay, and (iv) protection fo employment in the constitution (with equal weights). They also report similar results using the HeckmanPages job security index. Additional evidence of EPL effects on job mobility are discussed below, Section $\mathrm{X}$.

The large variation in labor regulations across states makes India a useful policy laboratory. Besley and Burgess (2004) provided evidence of a substantial, negative effect of a composite "pro-worker" labor standards index on employment, investment, output, and productivity in the regulated sector. The composite indicator includes of course severance pay mandates, but also dismissal appeals processes and collective bargaining regulations.

Although Bhattacharjea (2006) raised questions about the composite indicator of proworker regulation used by Besley and Burgess, Ahsan and Pagés (2008) reproduced the Besley and Burgess findings on a corrected data set, and added a refinement. They partitioned the "pro-worker" labor standards index into two regulatory subcomponents: (i) a labor dispute regulation indicator and (ii) an EPL indicator. They found that: "pro-worker" labor dispute resolution regulations had a larger and more systematic negative effect on employment and output than did pro-worker employment protection regulations, suggesting that collective bargaining laws are more critical than employment protection legislation in depressing employment. The labor dispute regulations were especially strong in heavy industry, with EPL disproportionately affecting labor intensive industries such as textiles.

In another study of broad labor standards, Forteza and Rama (2006) found little evidence of a negative labor standards effect on economic growth in a macro cross-national study. The authors used two measures of labor market rigidity, (i) the number of ILO 
"conventions" a country had ratified; and (ii) an aggregate indicator of minimum wages, mandated benefits, labor union strength, and size of government employment, as well as each separately. ILO conventions of course cover a wide range of standards on collective bargaining, minimum wages, and working conditions in addition to aspects of severance pay. Mandated benefits in Forteza and Rama's aggregate measure did not include dismissal pay because of limited data availability. Forteza and Rama added an additional element, the timing of World Bank-assisted economic reforms, and explored the impact of the various labor market rigidity measures on WB reform effects on GDP growth rates in 119 countries over the period 1970-1996.

On average the timing of reform (reduced labor standards) had no significant impact on growth. However, the authors found that reform effects were stronger and more efficient (GDP growth-beneficial) when a country already had in place flexible labor markets. Incremental labor reforms may have zero or negative impacts on growth when labor markets are inflexible. This conclusion held more strongly if the policy-aggregate measure of labor market rigidity was used rather than the ILO convention measure. Of special interest, when the four disaggregate policy indicators were separately analyzed, it was union strength and size of the government (employment) sector that appeared to have the most damaging effects on reform, not mandated benefits nor minimum wages (again severance pay was not included in the policy vector).

Summarizing these latter studies, it would appear that (i) vigorous government intervention in the labor market discourages employment, (ii) that this is especially true of collective bargaining laws, and (iii) that reforms (reduced intervention) are more likely to have measurable salutary effects if the labor market is already relative flexible. The last may explain why reforms, when they come, are often broad.

\section{Broad Economic Reforms and their Consequences}

In the sections to follow a number of micro studies will be reviewed. Many exploit natural experiments in order to estimate policy effects on economic outcomes. It is critical in these studies to be aware of the full set of policies implemented. Serious problems of 
interpretation arise if a particular reform experiment includes a large number of reforms, not just severance pay reforms. Two Latin American reforms, those of Columbia and Peru, provide concrete examples of the concern.

Columbia. The danger of attributing severance plan effects to a much broader "reform" package is illustrated in a series of studies of the Columbian Labour Market Reform of 1990 , Kugler $(1999,2002,2004$, and 2005). The basic approach in the various studies is quasi-experimental and difference-in-difference, with the change in the dependent variable of interest among covered workers (the formal sector) before and after the reform date compared with the change pre and post among uncovered workers. Among the reported impacts of this legislation:

(i) Exit rates out of employment and unemployment and unemployment levels increased, Kugler (1999)

(ii) "worker flows into and out of unemployment and its implied net effect on unemployment increased," Kugler (2004, p.184), and

(iii) wages of workers in the formal sector fell, Kugler $(2002,2005)$.

The approach is sound and the estimates of the impact of institutional change on these measures are plausible.

The problem is one of interpretation. The claim is that these processes are primarily driven by firing cost reform. The Columbian experiment is prominently described as having "substantially reduced dismissal costs," Kuglar (2005), and to have led to "a reduction in firing costs," Kugler (1999, Abstract). ${ }^{29}$ As it happens the impact of the reform on firing costs was limited and could well have increased. Specifically the severance insurance component of labor market regulation, unjust dismissals, was made more generous, 33 percent more generous, though only for those with ten or more years of service. For workers with lesser years of service, severance insurance benefits were unchanged. Offsetting that direct increase in severance insurance were other reforms that could have potentially reduced firing costs: (i) workers with ten years or more of service could no longer sue for back pay and reinstatement; (ii) the definition of just dismissal was modestly relaxed; and (iii) the 
bounds of temporary contracts were modestly expanded (Before the reforms, but not after, employers had to offer temporary contracts of at least a year.)

In sharp contrast to the ambiguous and possible perverse reforms of severance insurance plans, changes in severance savings account rules-though having only second order effects on firing costs--were substantial. Scanning these papers, for example, one finds the following redesign of the severance savings mandate:

(i) an increase in the formality of a mandated severance savings plan (employers had to deposit the savings into individual third party accounts rather than payout the savings account upon job separation);

(ii) the savings account was shifted from a defined benefit plan to a defined contribution plan.

(iii) Borrowing from the savings plan for education and housing was deducted from the worker's final separation payment differently. Before the reform extant worker borrowings were deducted as a nominal amount, after the reform as a real amount, discounted for inflation.

Changes in administrative rules for severance savings accounts are unlikely to move economies. Broader reforms might, and indeed, at almost the same time, there were serious reforms of capital markets and tariff policies:

In 1990, Law 45 eliminated interest rate ceilings, eliminated investment requirements in government securities and reduced reserve requirements....In addition,, Law 9 of 1991 eliminated exchange controls,... reducing restrictions on capital flows," Eslava, Haltiwanger, Kugler, and Kugler (2006, p. 61)).

and

The gradual decrease in tariffs initiated by the preceding Barco government was accelerated by Gaviria after June 1991. By the end of $1991, \ldots$ effective protection [reached] 26.6 percent,..down from 62.5 percent a year earlier.... Eslava, Haltiwanger, Kugler, and Kugler (2006, p. 61).

These reforms could have increased turnover and induced a wage decline equivalent to 6080 percent of the mandated contribution to the worker's severance savings accounts, but it is unlikely to have been caused by changes in "firing costs." 30

Peru. For similar reasons, one must interpret cautiously the findings of Saavedra and Torero (2004). They analyzed a large labor reforms in Peru in the early 1990s:

29 See also variants of this claim in Kugler (2004)

30 Kuglar (2004, pp.199-200) noted the pervasiveness of the reforms, but remained optimistic that her results reflect "firing cost" effects. 
In 1991, labor market regulations were relaxed through a succession of reforms. Firing costs diminished sharply through the progressive elimination of job stability regulations, the reductions in red tape for the use of temporary contracts, and

changes in severance pay structure. Saavedra and Torero (2004, p.132).

They employed the Heckman and Pagés measure (a hiring cost measure of severance pay), namely expected lifetime severance payouts, with the severance payout in each period weighted by the likelihood of being laid off in the period and summed.

In this case there were major changes to the severance insurance plan. The dismissal pay schedule was reduced sharply--from 12 months pay for displaced workers with 3 or more years of service to one month pay per year of service, Saavedra and Torero (2004, p.135, Figure 2.1). Saavedra and Torero reported that the measure has a negative and significant impact on employment. The measure also has the expected effects on various employment hazard functions.

Unfortunately (for experimental purposes) many other reforms occurred simultaneously with the reduction in dismissal pay. These included trade liberalization, downsizing of the public sector, the start of a privatization process, the abolition of all stateowned monopolies, a tax reform, easing of capital account restrictions, and deregulation of the financial sector, Saavedra and Torero (2004, p.131). It would seem impossible to isolate severance pay effects on output, employment, or even turnover in this welter of reforms.

One dramatic outcome that emerges despite the large reduction in mandated severance benefits is a precipitous drop in permanent contracts with the reduction in red tape for temporary contracts, which would appear to signal that firing costs remained high (other than through the use of temporary contracts). Saavedra and Torero reported that the share of permanent contracts among private salaried workers in Lima dropped from 80.1 percent in 1991 to 68.6 percent in 1992 (Saavedra and Torero 2004, Table 2.3, p.140).

Apparently large scale economic reforms can induce large, positive changes in labor market performance in extremely rigid environments. The implications for severance pay are however limited.

\section{Employment Protection Legislation (EPL) and Worker Separations}


A number of recent studies have, in the spirit of the OECD analyses, estimated EPL effects, usually under the hopeful assumption that other labor market and broader economic reforms were not implemented simultaneously. ${ }^{31}$ Several, using cross-national data sets, have focused on the first critical steps in the EPL mechanism—-the impact on dismissal rates and on job flow rates, the sum of accession and separation rates. Of special note, two recent job flow studies, Micco and Pagés (2006) and Haltiwanger, Scarpetta, and Schweiger (2008), arrived at remarkably similar conclusions on the basic question-the impact of "firing costs" on job flows. The studies used somewhat different data bases over somewhat different time periods and implement different strategies for estimating firing cost effects on job flows, which makes the similarity of conclusions reassuring.

Micco and Pagés estimated the impact of two EPL measures from Botero et al (2004), the monetary cost of dismissal and the administrative cost of dismissal, on job flow rates. $^{32}$ The sample was cross-national, including 11 developed countries and seven Latin American countries (including Mexico) during the 1980s and 1990s. The research design was a difference-in-difference structure in which employment volatility across sectors in the U.S. was used to identify sectors likely to be especially sensitive to EPL.

Haltiwanger, Scarpetta, and Schweiger employed a different EPL measure, the Fraser Institute's Economic Freedom of the World (EFW) index of hiring and firing costs. This is a seven category index, which makes quantitative comparisons impossible. ${ }^{33}$ The sample was also somewhat different, 16 countries in the 1990s, including seven OECD countries, five Latin American countries (again including Mexico) and four Eastern European

\footnotetext{
${ }^{31}$ Recall also the Caballero et al (2004) paper discussed in Section VIII.

32 Unfortunately, the authors did not believe that they could reasonably identify the independent impacts of (i) monetary costs of dismissal measure and (ii) administrative costs. They report a simple correlation of 0.71 between the two and estimate only the sum (2006, p.14).

33 For completeness: "Hiring and firing regulations: This sub-component is based on the Global Competitiveness Report's question: "The hiring and firing of workers is impeded by regulations $(=1)$ or flexibly determined by employers (=7)." The question's wording has varied slightly over the years. Source World Economic Forum, Global Competitiveness Report (various issues)." Gwartney, James, and Robert Lawson, Economic Freedom of the World, 2009 Annual Report, Economic Freedom Network (2009, p.198). Haltiwanger, Scarpetta, and Schweiger (2008, p.20) report that the measure is highly correlated with the OECD EPL measure-with a correlation of 0.85 .
} 
countries. The difference-in-difference estimation design also relied on the belief that the highly volatile sectors are most likely to be affected by EPL. They implemented this idea through firm size, arguing that small firms are more volatile, with the U.S. again used as a key benchmark. Both studies also included broad indices for the likelihood of enforcement of regulations.

The two studies arrived at similar conclusions. Micco and Pagés reported that "Our analysis indicates that more stringent legislation slows down job turnover by a significant amount, and that this effect is more pronounced in sectors that are intrinsically more volatile. Employment and output effects are driven by a decline in the net entry of firms." (2006, Abstract). Of special note, the impact of EPL effects on the expected sectoral variation in job reallocation (based on US values) is greater the greater the "rule of law," leading the authors to conclude that "...the effect of EPL on job flows is not statistically significant in countries that score low in the rule of law measure." Micco and Pagés (2006, p.19). ${ }^{34}$

Similarly Haltiwanger, Scarpetta, and Schweiger $(2008$, p.5) found "...support for the general hypothesis that hiring and firing costs reduce turnover, especially in those industries and size classes that require more frequent labor adjustment." They added the refinement that "...stringent labor regulations have more of an impact on job flows resulting from the entry and exit of firms than from reallocation among incumbents." Haltiwanger, Scarpetta, and Schweiger (2008, p.5).

The predicted impact of EPL on job reallocation is roughly comparable in the two studies. Based on a simple model, Micco and Pagés (2006, p.18). report that the reallocation rate "in an industry in the $90^{\text {th }}$ percentile of flexibility requirement relative to an industry in the $10^{\text {th }}$ percentile is 6.31 percentage points lower in a country with strict employment protection (that is in the $90^{\text {th }}$ percentile of job security) than in a country with low employment protection (in the $10^{\text {th }}$ percentile)." (The average reallocation rate was 20

\footnotetext{
${ }^{34}$ The rule of law measure derives from Kaufmann, Kraay, and Mastruzzi (2003).
} 
percent.) Haltiwanger, Scarpetta, and Schweiger (2008, p.22) estimate a 4.4 percentage point decrease on a base of 25 percent.

Conversely, using a natural experiment, Bauer, Bender, and Bonin (2007, p.804) reported, "In contrast to the predictions of the theory, our results indicate that there no statistically significant effects of dismissal protection legislation on worker turnover." Too much can be made of this finding. Experiments may fail to generate reliable estimates of consequences either because the effect was indeed small or because the treatment was modest. The latter appears to be the case in this study.

A careful review of the German quasi-experiment makes their conclusion unsurprising—it was an experiment in which almost nothing happened. In October of 1996, the small firm exemption for dismissal regulations was raised from five employees to ten employees, seemingly freeing employers with five to ten employees from that regulatory burden. But in March 1999, the policy was reversed and the lower threshold was restored. Without further detail one might imagine this to be an excellent experiment, with the employment behavior of the 5-10 employee firms between 1996 and 1999 providing a measure of unconstrained behavior. Alas the experiment was much less straight-forward than that with the the authors reporting that

...the amendment immediately affected only new hires. Those already employed were guaranteed the original level of protection against dismissal for a transition period of three years. Even before the provisions for a gradual transition had expired, in January 1999, dismissal protection legislation was tightened again, by returning to the original threshold value of five employees. Bauer, Bender, and Bonin (2007, p.808).

For the great bulk of the workforce, there apparently was no experiment, only the broken promise of one in the future.

Another recent job flow study considers a more complex effect model. In a crossnational study, Messina and Vallanti (2007) assessed the impact of firing restrictions on job flows-job reallocation as well as its components, job creation and destruction--in a sectoral sample of fourteen European countries (roughly the EU15) from 1992 to 2001 . The study 
relied on a single homogenous data base (Amadeus), and used the OECD (2004) index of EPL strictness as the measure of firing costs. ${ }^{35}$ They concluded, reasonably enough:

"More stringent firing laws dampen the response of job destruction to the cycle, thus making job turnover less counter-cyclical. Moreover, stricter EPL reduces both the creation and destruction of jobs in declining sectors relative to expanding sectors, implying that faster trend growth attenuates the impact of firing costs on firm's hiring and firing decisions.." Messina and Vallanti (2007, Abstract, F279).

It is plausible to conclude from these studies that more aggressive EPL reduces job separation rates, and therefore accession rates, although one cannot rule out the possibility that these effects are the result of simultaneous, unobserved reforms of other sorts. In any case, the implications for severance benefit generosity alone are limited.

\section{Employment Protection Legislation (EPL): Employment and its Distribution ${ }^{36}$}

If job protection regulations indeed protect the employed, reducing job flows, the impact on those who do not yet hold jobs is likely to be negative, but the precise impact is likely to vary across economies. In developing countries, the regulations may affect the distribution of jobs between the formal sector and the informal sector. In advanced economies this might be reflected in redistribution between wage employment and selfemployment. Predictions about aggregate employment effects of job security (and certainly their welfare implications) become yet more difficult when low protection employment options, "temporary contracts," are introduced as they were in a number of OECD countries in the 1980 s and 1990s. ${ }^{37}$

The OECD studies discussed in Section VII suggested that employment rates in aggregate are lower in countries with strict EPL, with only employment rates for prime age men higher, OECD $(1999,2004)$. EPL may also explain the high rates of temporary jobs among the young and the less skilled. Additional, micro evidence, both natural experiments and cross-national studies, are reviewed in the remainder of this section.

\footnotetext{
35 They also conduct a robustness test using a less commonly used EPL measure developed by Blanchard and Wolfers (2000). Here as elsewhere, the exact form of the EPL measure does not seem of critical importance.

36 See Kugler (2007) for some interesting reflections on this literature.
} 
Italy (1990). One reform, this in Italy in 1990, has been the subject of intense study. Both before and after the "reform," dismissal rules were more stringent for employers with more than 15 workers than for those with 15 or less, but the reform sharply narrowed the size advantage of small firms.

For larger firms, the rules were unchanged. Rules were specified for two types of dismissal, individual and collective, from permanent contracts. Although not exclusively so, individual dismissals were typically for disciplinary reasons, collective for economic reasons. One additional concept was critical, "just cause." Both individual dismissal and collective dismissal were allowed only with just cause; severe penalties were imposed for releasing a worker without that designation. A worker found by the courts to have been released without just cause was eligible for foregone wages between dismissal and the court ruling, which could be as much as five years, and given the choice of either reinstatement or a lump sum payment of another 15 months. The firm had the burden of proof that the dismissal was just, which is notably more difficult for disciplinary dismissals.

Conversely, the treatment of small firms changed significantly in 1990. Before 1990, small firms, those with less than 16 workers, were exempt from any such rules. After 1990, small firms were also penalized for unjust dismissal, with the firm choosing between reinstatement and severance pay of 2.5 to 6 months pay. The change sharply increased firing costs for small firms, but also sharply reduced disincentives to expansion beyond 15 workers should that be efficient.

Kugler and Pica (2008) used this quasi-experiment to isolate the severance mandate effect on turnover and total employment. They reported, "We find that the increase in dismissal costs decreased accessions and separations for workers in small relative to large firms, especially in sectors with higher employment volatility, with a negligible impact on net employment." Kugler and Pica (2008, p.78). The reform effects on turnover were modest, given the generosity of the severance mandate imposed, about a 15 percent reduction in

37 Dolado, Garcia-Serrano, and Jimeno (2002) provide a detailed account of the most dramatic of 
separations and a 13 percent reduction in accessions. At the extensive margin, there appeared to be a significant reduction in entry of small relative to large firms but oddly no apparent effect on exit of small firms relative to large, Kugler and Pica (2008, Table 3, p.89).

In a two-part analysis, Boeri and Jimeno (2005) first established (on post-reform data) that the EPL rules remained significantly more stringent for large firms after the 1990 reforms. Using the temporary vs. permanent contract distinction in a difference-in-difference framework, they reported that dismissal rates remained sharply lower in large firms, or to quote them, "Workers under permanent contracts in firms with less restrictive EPL are more likely to be dismissed." (Boeri and Jimeno (2005, p. 2057).

They then considered the reform period. The fact that the extension applied only to workers under permanent contracts set up the possibility of a double difference approach: is the behavior of workers under permanent contracts in firms of less than 15 workers firms different from those in all other circumstances. The authors used this approach to estimate reform effects on firm employment size. They reported that the reform increased the "persistence" of small firms in the small firm category, (mildly, but significantly in a logit model), which seems a little odd since the reform leveled the playing field between small firms and large. They found no evidence of an impact on employment growth (change).

Schivardi and Torrini (2008) found modest effects of the EPL threshold of 15 workers on firm growth just above and below the threshold, estimating that the "probability of firms' growth is reduced by around 2 percentage points near the threshold." Schivardi and Torrini (2008, p.482). They also noted the impact of the 1990 reform. "The results...show indeed that the threshold effect, equal to around 2 percent before 1990, drops (in absolute value) by between .7 and 1 percentage point in the second part of the sample." Schivardi and Torrini (2008, p.497)).

In sum, the EPL effects on employment appear small and possibly perverse (relative to the simplest severance mandate interpretation).

these, Spain. 
Spain. Kugler, Jimeno, and Hernanz (2005) explored the distributional consequences of restrictive dismissal policies and payroll taxation of permanent contracts on employment in the Spanish labor market. Reforms in 1997 and extended in 2001 were designed to make permanent contracts more attractive to firms for two demographic groups, younger workers and older ones. The reforms were substantial, though not limited to dismissal policies:

Severance payments for unfair dismissals of newly signed contracts of workers in affected groups were reduced from 45 to 33 days per year of seniority and the maximum was reduced from 42 to 24 months. In addition, given the high payroll tax rate in Spain (i.e. $28.3 \%$ of the salary), the reform reduced payroll taxes between $40 \%$ and $90 \%$ for workers in these population groups hired under new permanent contracts. (Kugler, Jimeno, and Hernanz 2005, p.7).

Relief from dismissal mandates and from payroll taxes was offered for conversion of temporary contracts to permanent contracts.

As reported by Heckman and Pagés for a broad sample of OECD and LAC countries, Table 1, expected dismissal costs are typically quite modest relative to payroll taxes, and that is the case in the Spanish example--both prior to the reforms and after. The authors estimated "quarterly expected dismissal costs of 17 and 191 Euros for young and older men, respectively [in 1995].... The payroll tax rate is $28.3 \%$, implying an average quarterly payroll tax cost of 756 and 1,478 Euros for young and older men, respectively" (Kugler, Jimeno, and Hernanz 2005, p.20).

The authors reported that: "Our results suggest the Spanish reforms increased permanent employment probabilities for young and older men." Kugler, Jimeno, and Hernanz (2005, p.2). "In addition we find some evidence that reduced non-wage labor costs for contract conversions increased transitions from temporary to permanent employment for men of all age groups. On the other hand....we find little effect of subsidies and reduced dismissal costs on women." Kugler, Jimeno, and Hernanz $(2005$, p.3). There is no obvious explanation for the sex differences in response. ${ }^{38}$ That said, the vastly greater magnitude of

\footnotetext{
38 The authors argue, "...weak effects on women seem to reflect the lack of a good control group as well as pre-existing trends for women." Kugler, Jimeno, and Hernanz (2005, p.22).
} 
the payroll tax reduction relative to changes in expected dismissal costs would seem to argue that the behavioral consequences can be attributed largely to the payroll tax.

Chile. Montenegro and Pagés (2004) provided evidence from Chile, which imposed job security mandates of sharply varying severity over the period 1960-1998, including an eightfold increase in 1965 and a fifty percent reduction in the early 1970s. The job security measure was a Heckman-Pagés gross hiring cost measure, the probability-weighted sum of advance notice, justified dismissal, and unjustified dismissal payments, Montenegro and Pagés (2004, p.408). The timing of major changes was not random, which raises the usual concerns that the authors may be picking up broader labor market and economic changes (they do control explicitly for minimum wages). This study could well belong in the review of "economic reforms" above.

In any case, the authors embedded this policy measure in annual June household survey data, and found that the employment of prime age males rose with greater job security (at the $5 \%$ to $10 \%$ confidence level depending on specification), but that the employment of others declined. In particular, "job security regulations reduce the employment opportunities of the young and the unskilled-and particularly unskilled youthwhile promoting the employment rates of skilled and older workers." Montenegro and Pagés (2004, p.431). They also found "indications that job security regulations may force some workers, particularly women and the unskilled, out of wage employment and into selfemployment." Montenegro and Pagés (2004, p.431).

Canada, Finland, Italy, the Netherlands, Switzerland, the U.K., and the U.S. Kahn (2007) analyzed the impact of EPL on the demographic patterns of nonemployment and temporary employment for six countries, Canada, Finland, Italy, the Netherlands, Switzerland, the U.K., and the U.S. He employed a relatively unused (for these purposes) microsurvey data set, the 1994-1998 International Adult Literacy Surveys, which contains information on job type, permanent or temporary. His EPL measure is the "OECD permanent employment protection indicator," Kahn (2007, p.F342). Kahn found, "that greater protection disproportionately lowered the relative probability that youths, immigrants 
and, possibly, women were employed; in addition, among those with jobs, I generally found that greater employment protection also lowered the relative incidence of permanent work among these groups, as well as those with low cognitive ability," Kahn (2007, p. F354).

Kahn included explicit controls for collective bargaining rules so that the EPL effects are not simply a reflection of broader labor market interventions. Collective bargaining rules redistributed jobs in much the same way as EPL. ${ }^{39}$ Of special interest, he found that the combination of strong EPL and strong collective bargaining rules compounded the individual policy effects--the combined effect is larger than the sum of the two individual effects, not smaller. The two sets of rules are not simply alternative means to the same ends.

The evidence seems quite compelling that labor legislation, perhaps even employment protection legislation, does what one might imagine it would do---reduce the separation rate of those with jobs, often prime age adults, at the expense of new entrants and the more highly mobile--the young and the less skilled.

\section{EPL as Workplace Control}

EPL measures are of course a mixture of severance benefit generosity, access to less protected temporary jobs, and work discipline constraints. One cannot ignore the contribution of work discipline constraints in this mix. There is reasonable evidence that such constraints have significant and negative effects on employment. The effects are modest if the constraints on work place control are small, and more substantial if the constraints are severe.

An event of the first type is the much studied shift in the legal shift of the employmentat-will doctrine in the U.S., Dertouzos and Karoly (1993), Miles (2000), Autor, Donohue, and Schwab (2004, 2006), and MacLeod and Nakavachara (2007), among others. In a remarkably brief period--the 1980s--U.S. state courts moved away from a narrow interpretation of employment-at-will contracts (that, in the absence of a written contract to

39 On collective bargaining effects, see also Bertola, Blau, and Kahn (2007), who found for 17 OECD countries over the 1960-1996 period that "time-varying indicators of unionization decrease the 
the contrary, employers are free to release workers at will). ${ }^{40}$ Courts began systematically overriding employment-at-will for a variety of reasons, many of which might seem unexceptional to an economist. Seemingly narrow exceptions include: (i) that a worker can sue for wrongful discharge if released because she refuses to break a law (the public policy exception), or if the intent is to deny her delayed compensation due her (the good faith exception). Many state courts embraced a more substantial exception, that of implicit contracts. By 1990 for example, workers in all states could sue for wrongful discharge if they had been released despite having foregone an outside opportunity on a (nonwritten) promise of continued employment with the firm.

The implicit contract exception strikes a contractarian as logical, which makes the change potentially efficiency augmenting. Much depends on the efficiency of the courts, which become more important players in the employment relationship because judgment is required. If courts function badly, the additional discretion might reduce labor market efficiency. State courts vary in quality, which makes empirical study of the consequences of this change especially interesting.

In the seminal paper on this topic, Dertouzos and Karoly (1993) reported statistically significant, but small, negative employment effects of the employment-at-will events of the 1980s. Miles (2000) undertook a careful reexamination of the same basic empirical phenomenon and reported that he found no significant employment effects, though he did find large temporary employment gains. The speed of the conversion and the localization of its timing—beginning in the high income states and spreading rapidly to the low, Southern states-makes empirical assessments of effects somewhat tricky; the "low income" states grew more rapidly throughout the period and also adopted temporary contracts later. Autor, Donohue, and Schwab $(2004,2006)$ generally supported Miles' conclusions, finding that employment effects of the weakening of employment-at-will contracts had little effect on

employment-population ratio of young and older individuals relative to the prime-aged, and of primeaged women relative to prime-aged men..." (p.833).

${ }^{40}$ Miles (2000) provides an especially clear introduction to the event. 
employment, although the estimated coefficient on one policy variation, though small in absuolute magnitude, was significantly different from zero (and negative as expected). Their modifications "restore the conclusion that the implied contract exception caused a small but significant employment reduction." Autor, Donohue, and Schwab (2004, p.445). ${ }^{41}$

MacLeod and Nakavachara (2007), while finding essentially zero aggregate employment effects of the legislated changes, noted an interesting effect once the labor force was disaggregated by skill. Evidence emerged that highly skilled workers experienced positive, though small, employment effects, low skilled workers small, negative effects. The first result, at least, is consistent with the argument that the contracting environment for specific human capital had improved. Apparently the U.S. state court systems function sufficiently well that the additional responsibilities interpreting the employment contract did not have a large, negative effect on labor market efficiency.

That does not mean that larger shifts in workplace control would not have more substantial effects. Marinescu (2009) provided evidence from the United Kingdom that larger shifts in job separation regulations could have significant effects on job security independent of severance pay mandates, at least for short tenured workers, primarily youth. In 1999, the probationary period for permanent employment was lowered from two years to one, while regulations on severance pay and advance notice were unchanged (Footnote 7 , pp.469-470). Marinescu (2009, Footnote 4, pp.469) describes the bureaucratic aspect of job protection following the probationary period in the following way:

...if a worker is dismissed (i.e. for cause) or made redundant (laid off) and satisfies the relevant conditions, he can sue his former employer claiming that the dismissal was unfair. The Employment Tribunal decides on the case. If the worker's claim is found to be legitimate, the firm has to pay the worker a compensation that is largely based on the worker's age and seniority.

One might view this as an administratively determined severance payout of uncertain size. However it is viewed, reducing the exclusion from this process from two years to one had a large, negative impact on involuntary worker turnover in the one to two year tenure interval.

\footnotetext{
${ }^{41}$ Autor (2003) reconfirmed (and expanded upon) Miles' claim of a temporary employment effects.
} 
As Marinescu (2009, p. 465) reported, "The firing hazard for these workers decreased by $26 \%$ relative to the hazard for workers with $2-4$ years of tenure."

Oddly the firing rate of those with less than one year of tenure also fell, and by only a slightly smaller amount (19\%), though one might have expected an increase in separations in the now shorter probationary period, Marinescu attributes this apparent anomaly to better recruiting practices induced by the shorter probationary period. Like other curious results that pop up in natural experiments, this explanation might be correct but it does raise concern that omitted forces are at work.

\section{Severance Pay Generosity}

We have at least some evidence, then, of dismissal regulation effects on involuntary turnover independent of severance generosity. What of the converse? Is there similar direct evidence that the severance generosity dimension of EPL alone has significant effects on turnover and employment? The Lazear study appropriately reinterpreted [Addison, Teixeira, and Grosso (2000)] and the Heckman-Pagés (2004) study both provide severance generosity estimates, though one must be a little concerned about correlated, omitted policy variables in these studies. Taken at face value, the studies yield no statistically significant evidence of severance pay generosity effects on aggregate employment, or for that matter unemployment. OECD studies $(1999,2004)$ provide estimates of EPL effects, though severance pay implications are limited by the ex ante policy weights.

Additional evidence does exist. Friesen (2005) exploited variations in Canadian severance pay and other employment protection laws to assess the effects on layoff risk. She analyzed survey data from 1988-1990 to estimate the impact on the layoff hazard of variations in mandated individual and group advance notice and severance pay mandates. Each province, territory, and the federally regulated sectors has its own employment protection legislation, and variations across provinces are substantial, particularly for advance notice mandates. Unfortunately severance pay mandates are found only in Ontario and the Federal jurisdiction. 
She found evidence of negative effects on the layoff hazard to employment (shortened job duration) for individual advance notice requirements, but not for severance benefit mandates. The absence of measured severance effects may reflect the limited magnitude of variation in severance mandates. Ontario mandated one week of severance for each year of tenure up to 26 weeks, a common level in voluntary plans in larger U.S. firms. Mandates in the federally regulated sectors were smaller.

Sri Lanka. A natural experiment that involved quite large changes in severance generosity mandates is described by Vodopivec (2004). In 1971 Sri Lanka imposed an unusually generous severance mandate on most large firms, which would seem to offer hope of providing robust estimates of severance effects on labor market activities of various sorts. The objective of the underlying legislation, the Termination of Employment of Workman Act (TEWA) of 1971, was protection against mass layoff, not discharge for cause. $^{42}$ In 2002, "a Sri Lanken worker with 20 years of service received an average severance package equal to 29 months of wages," [Abidoye, Orazem, and Vodopivec (2009, p.6)]. A laid off OECD worker with twenty years of experience might expect 5 or 6 months.

Abidoye, Orazem, and Vodopivec (2009) explored the impact of this extraordinarily high level of mandated severance pay for larger firms on employment growth by firm size. The study relied on two special features of the legislation and its enforcement, that firms with fewer than fifteen workers were legally exempt, and that firms in export processing zones (EPZ) were uncovered due to the laxity of enforcement. ${ }^{43}$ These set up a difference-indifference approach to employment growth rates (measured as the fraction of firms that expanded employment). As Figure 3 indicates, firms below the legislated threshold were less likely to add workers than were large firms, though somewhat surprisingly (i) the effect

\footnotetext{
42 "The TEWA was intended to prevent or discourage mass retrenchment situations in the industrial sector, considered to be likely due to the scarcity of raw materials during a period of inward-looking economic policy in the early 1970s." Heltberg and Vodopivec (2009, p. 17).

${ }_{43}$ "...firms in Export Processing Zones (EPZ) are said to face lax policy enforcement..." Abidoye, Orazem, and Vodlopivec (2009, p.3.)
} 
is less dramatic among threshold firms (size 14) than smaller ones, and (ii) the size effect holds for EPZ firms, in which no regulations are believed to hold, as well as in non-EPZ firms, where they are [which supports the wisdom of using a difference-in-difference approach]. As it happens, the threshold effect is yet smaller in a difference-in-difference structure--the differential between employment growth in the regulated and unregulated sector for firms with 14 employers was less than for either smaller or larger firms.

The authors developed arguments as to why threshold firms have smaller growth responses than other small firms in response to these extraordinary severance mandates, but the modest, perhaps perverse, threshold growth response argues against serious severance pay concerns. ${ }^{44}$ An alternative hypothesis is that policy enforcement was lax throughout the economy, not simply in the EPZ. ${ }^{45}$ Unusually large severance mandates may appear only where regulation enforcement is weak. Similar mandates in an OECD country might have quite different results. ${ }^{46}$

I am unaware of anyone who has estimated the job distributional effects of a simple variation in severance pay generosity.

\section{Conclusion}

The Lazear paradox--that the firing cost consequences of severance pay mandates are easily avoided yet observed (adverse) effects are large-appears to be resolved through accumulating evidence that adverse effects of a mandate are small without explicit contract avoidance. The substantial voluntary provision of severance pay in the U.S. is one clear signal that the distortions are not large. A critical review of the extensive empirical literature on mandate effects supports that interpretation: severance mandates, unaccompanied by other labor regulations, have little impact on worker separations (or accessions) or average employment levels, the labor processes considered here.

\footnotetext{
44 There is also some question of how closely the program otherwise approximates a severance savings plan.

45 The authors do report the case of one luckless international company, Shell Gas Lanka, that was not spared the full measure of the law (Appendix 1, p.37).
} 
This conclusion is not always apparent in individual studies. Sufficiently broad interventions in the economy do have substantial negative consequences, and the challenge is to disentangle the effects of these more substantial policies on that of severance pay generosity alone. Employment protection legislation and even severance pay cover a complex of policy instruments, only one of which is job displacement insurance. An even greater impediment for empirical analysis of severance mandate effects is that changes in mandate requirements are typically embedded in broad policy "reforms," positive and negative, making the identification of severance policy consequences difficult.

Evidence of adverse efficiency effects of government interventions is most compelling when the range of interventions is large. Summarizing

1. Comprehensive government intervention in the economy--heavy tariffs, highly regulated product and factor markets, including capital controls and capital market restrictions as well as those in the labor market--have large, negative effects on the labor market. Conversely broad economic "reforms" easing these restrictions yield large, positive gains.

2. Broad labor regulations, especially with regard to collective bargaining and dispute resolution, appear to have large, negative effects on the labor force and the economy.

3. Employment protection legislation (EPL) - a combination of severance pay mandates, advance notice mandates, and limits on disciplinary discharges--appears to have substantial, negative effects on worker separations and accessions, and therefore aggregate turnover.

4. Although there is little compelling evidence of strong EPL on employment levels; a "best" estimate might be that there is a slight negative effect on employment.

5. Evidence of EPL distributional consequences is robust. EPL restrictions make permanent contracts more difficult for new workers to secure, which favors "prime age" men at the expense, most consistently, of the young and the low skilled, and, in some circumstances, women and older workers.

6. At least some evidence exists of the importance of more complex processes:

a. the impact of EPL reforms

i. is conditioned on obedience to the law in general;

ii. may depend on the regulatory environment in the economy as a whole;

b. there may be important interaction effects between severance mandates and collective bargaining rules.

46 Recall the Caballero et al (2004) findings that employment security measures only (adversely) affect the speed of employment adjustment to a shock if the "rule-of-law" is strong. 
Identification of the EPL factors responsible for observed distortions remains an important issue for further research. A variety of results point toward workplace control, including the employer's ability to release unsatisfactory workers, and collective bargaining rules.

The lesson for job displacement insurance designers is that indirect mandate effects appear to be modest over the range observed in industrialized economies. Benefit generosity can, to a first approximation, be set by the worker's demand for the insurance coverage without concern for moral hazard effects on turnover and equilibrium employment. Larger mandates appear to have only modest indirect effects, although these are observed only in developing economies and enforcement may be spotty. 


\section{REFERENCES}

Abidoye, Babatunde, Peter F. Orazem, and Milan Vodopivec. 2009. "Firing Cost and Firm Size: A Study of Sri Lanka's Severance Pay System." mimeo.

Addison, John, and Paulino Teixeira. 2003. "The Economics of Employment Protection." Journal of Labor Research Vol. 24.1 (Winter): 85-129.

Addison, John, Paulino Teixeira, and Jean-Luc Grosso. 2000. "The Effect of Dismissals Protection on Employment: More on a Vexed Theme." Southern Economic Journal v. 67.1 (July): 105-22.

Ahsan, Ahmad and Pagés, Carmen, 2008"Are All Labor Regulations Equal? Evidence from Indian Manufacturing," IZA Discussion Paper No. 3394. 2008.

Almeida, Rita, and Pedro Carneiro. 2009. "Enforcement of Labor Regulation and Firm Size." Journal of Comparative Economics 37.1 (March): 28-46.

Autor, David H. 2003. "Outsourcing at Will: The Contribution of Unjust Dismissal Doctrine to the Growth of Employment Outsourcing. Journal of Labor Economics 21.1 (January): 1-42.

Autor, David H., John J. Donohue III, and Stewart J. Schwab. 2006. "The Costs of WrongfulDischarge Laws." Review of Economics and Statistics 88.2(May): 211-231.

Autor, David H., John J. Donohue III, and Stewart J. Schwab. 2004. "The Employment Consequences of Wrongul-Discharge Laws, Large, Small, or None at All?" AEA Papers and Proceedings 94.2: 440-446.

Bauer, Thomas K., Stefan Bender, and Holger Bonin. 2007. "Dismissal Protection and Worker Flows in Small Establishments.," Economica 74: 804-821.

Bentolila, Samuel and Giuseppe Bertola. 1990. "Firing Costs and Labor Demand: How Bad is Eurosclerosis?" Review of Economic Studies 57.3(July): 381-402.

Bertola, Giuseppe. 1990. "Job Security, Employment, and Wages." European Economic Review 34 (1990): 851-886.

Bertola, Giuseppe. 1992. "Labor Turnover Costs and Average Labor Demand." Journal of Labor Economics" 10(October): 389-411.

Bertola, Giuseppe. 1999. "Microeconomic Perspectives on Aggregate Labor Markets." Labor Turnover Costs and Average Labor Demand." in Orley Ashenfelter and David Card, eds. Handbook of Labor Economics Vol 3C Amsterdam: Elsevier 2985-3028.

Bertola, Giuseppe, Tito Boeri, and Sandrine Cazes. 2000. "Employment Protection in Industrialized Economies: The Case for New Indicators." International Labour Review 139.1: 57-72.

Bertola, Giuseppe, Francine D. Blau, and Lawrence M. Kahn. 2007. "Labor Market Institutions and Demographic Employment Patterns." Journal of Population Economics 833-867.

Besley, Timothy; and Robin Burgess. 2004. "Can Labor Regulation Hinder Economic Performance? Evidence from India." Quarterly Journal of Economics 119.1 (February): 91-134

Bhattacharjea, Aditya. 2006. "Labour Market Regulation and Industrial Performance in India: A Critical Review of the Empirical Evidence." Indian Journal of Labour Economics 49.2: 211-232. 
Bishow, John, and Donald O. Parsons. 2004. "Trends in Severance Pay Coverage in the United States. 1980-2001" (May) Available at SSRN:

http://ssrn.com/abstract=878144

Blanchard, Olivier. 1998. "Employment Protection and Unemployment." mimeo.

Blanchard, Olivier, and Pedro Portugal. 2001 "What Hides Behind an Unemployment Rate: Comparing Portuguese and U.S. Labor Markets?" American Economic Review 91 (March): 187-207.

Blanchard, Olivier, and Justin J. Wolfers. 2000. "The Role of Shocks and Institutions in the Rise of European Unemployment: The Aggregate Evidence." Economic Journal 110: C1-33.

Boeri, Tito, and Juan F. Jimeno." 2005. The Effects of Employment Protection: Learning from Variable Enforcement," European Economic Review 49.8: 2057-2077.

Boeri, Tito, Brooke Helppie, and Mario Macis. 2008. "Labor Regulations in Developing Countries: A Review of the Evidence and Directions for Future Research." Social Protection and Labor: The World Bank, SP Discussion Paper No.0833 October.

Booth, Alison L., Juan J. Dolado, and Jeff Frank. 2002. "Symposium on Temporary Work: Introduction," Economic Journal 112.480 (June): F181-F188.

Botero, Juan C.; Djankov, Simeon; La Porta, Rafael; Lopez-de-Silanes, Florencio; Shleifer, Andrei. 2004. "The Regulation of Labor." Quarterly Journal of Economics 119(4): November: 1339-82.

Caballero, Ricardo J., Kevin N. Cowan, Eduardo M.R.A. Engel, and Alejandro Micco. 2004. "Effective Labor Regulation and Microeconomic Flexibility," NBER Working Paper 10744 (September).

Dertouzos, James N.; and Lynn A. Karoly. 1993. "Employment Effects of Worker Protection: Evidence from the United States." in Christoph F. Buechtemann, ed. Employment Security and Labor Market Behavior: Interdisciplinary Approaches and International Evidence. Ithaca: ILR Press: 215-27.

Dolado, Juan J., Carlos Garcia-Serrano, and Juan F. Jimeno. 2002 "Drawing Lessons from the Book of Temporary Jobs in Spain. Economic Journal 112 (June): F270-F295.

Emerson, Michael. 1988. "Regulation or Deregulation of the Labour Market; Policy Regimes for the Recruitment and Dismissal of Employees in the Industrialized Countries." 1988. European Economic Review 32: 775-817.

Eslava, Marcela; John Haltiwanger, Adriana Kugler, Maurice Kugler. 2006. "Plant Turnover and Structural Reforms in Colombia." IMF Staff Papers, Special Issue 53: 58-75.

Forteza, Alvaro; and Martin Rama. 2006. "Labor Market 'Rigidity' and the Success of Economic Reforms across More Than 100 Countries." Journal of Policy Reform, 9.1 (March): 75-105.

Friesen, Jane. 2005. "Statutory Firing Costs and Lay-offs in Canada." Labour Economics12 147-168.

Garibaldi, Pietro, Lia Pacilli, and Andrea Borgarello. 2003. "Employment Protection Legislation and the Size of Firms." IZA DP No.787. May.

Gavin, Michael.K. 1986. "Labor Market Rigidities and Unemployment: The Case of Severance Costs." Federal Reserve International Finance Discussion Papers No, 284. http://www.federalreserve.gov/pubs/ifdp/1986/284/ifdp284.pdf

Goerke, Laszlo. 2006. "Earnings-Related Severance Pay." Labour 20.4 (December): 651672. 
Grubb, David, and William Wells. 1993. "Employment Regulation and Patterns of Work in EC Countries." OECD Studies 21: 7-58.

Gwartney, James, and Robert Lawson. 2009. Economic Freedom of the World, 2009 Annual Report, Economic Freedom Network p.198).

Haltiwanger, John, Stefano Scarpetta, and Helene Schweiger. 2008. "Assessing Job Flows Across Countries: The Role of Industry, Firm Size, and Regulations." NBER Working Paper 13920, April.

Heckman, James J., and Carmen Pagés. 2004. "Introduction," in Heckman and Pagés, eds., Law and Employment: Lessons from Latin America and the Caribbean Chicago, The University of Chicago 1-107.

Heckman, James J., and Carmen Pagés. eds. 2004. Law and Employment: Lessons from Latin America and the Caribbean Chicago, The University of Chicago 1-107.

Heltberg, Rasmus, and Milan Vodopivec. 2009. "Sri Lanka, Unemployment Job Security, and Labor Market Reform." mimeo, World Bank, January. Available at SSRN: http://ssrn.com/abstract=1208662

Holtzmann, Robert. 2005. "Editorial." Empirica. 32.3-4 251-253.

Holzmann, Robert, Yann Pouget, Michael Weber, and Milan Vodopivec. 2011. "Severance Pay Programs around the World: History, Rationale, Status, and Reforms" In Robert Holzmann and Milan Vodopivec, eds., Improving Termination Pay: An International Perspective, Washington, DC: World Bank (this volume).

Hunt, Jennifer. 2000. "Firing Costs, Employment Fluctuations and Average Employment: An Examination of Germany." Economica NS 67.266 (May): 177-202.

Ichino, Andrea, and Regina T. Riphahn. 2005. "The Effect of Employment Protection on Worker Effort: Absenteeism During and After Probation," Journal of the European Economic Association 3.1 (March): 120-143.

IFC, Cost of Doing Business 2009 http://www.doingbusiness.org/documents/fullreport/2009/Country Tables.pdf

Kahn, Lawrence M. 2007. "The Impact of Employment Protection Mandates on Demographic Temporary Employment Patterns: International Microeconomic Evidence." Economic Journal 117 (June): F333-F356.

Kaufmann, Daniel, Aart Kraay, And Pablo Zoido-Lobaton. 1999. "Governance Matters," World Bank Policy Research Department Working Paper 2196.

Kaufmann, David, Aart Kraay, and Massimo Mastruzzi. 2003. "Governance Matters III: Governance Indicators for 1996-2002." World Bank Research Department Working Papers, World Bank, Washington, DC (May).

Kraay, Aart, and Norikazu Tawara. 2010. "Can Disaggregate Indicators Identify Governance Reform Priorities?" World Bank Policy Research Working Paper 5254 March.

Kugler, Adriana D. 1999. "The Impact of Firing Costs on Turnover and Unemployment: Evidence from the Colombian Labour Market Reform." International Tax and Public Finance 6.3(August): 389-410.

Kugler, Adriana D. 2002. "From Severance Pay to Self-Insurance: Effects of Severance Payments Savings Accounts in Colombia." IZA Discussion Paper No. 434. February.

Kugler, Adriana D. 2004. "The Effect of Job Security Regulations on Labor Market Flexibility: Evidence from the Columbian Labor Market Reform," in Heckman and Pagés, Law and Employment: Lessons from Latin America and the Caribbean, Chicago, The University of Chicago 183-228. 
Kugler, Adriana D. 2005. "Wage-shifting Effects of Severance Payments Savings Accounts in Columbia." Journal of Public Economics 89: 487-500.

Kugler, Adriana D. 2007. "The Effects of Employment Protection in Europe and the USA." Els Opuscles del CREI 18 (February).

Kugler, Adriana, Juan F. Jimeno, and Virginia Hernanz. 2003 (2005 Version). "Employment Consequences of Restrictive Permanent Contracts : Evidence from Spanish Labor Market Reforms." C.E.P.R. Discussion Papers, CEPR Discussion Papers: 3724.

Kugler, Adriana D., and Giovanni Pica. 2008. "Effects of Employment Protection on Worker and Job Flows: Evidence from the 1990 Italian Reform." Labour Economics 1578 95.

Lazear, Edward P. 1990. "Job Security Provisions and Employment." Quarterly Journal of Economics 105(August): 699-726.

Lee Hecht Harrison. 2001. "Severance and Separation Benefits: Bridges for Employees in Transition," Woodcliff Lake, NJ: Lee Hecht Harrison.

MacLeod, W. Bentley, and Voroprapa Nakavachara. 2007. "Can Wrongful Discharge Law Enhance Employment." Economic Journal 117 (June): F218-278.

Malcomson, J. 1999. "Individual Employment Contracts" in Orley Ashenfelter and David Card, eds. Handbook of Labor Economics IIIB. Chapter 35, North Holland Press, 2291-2372.

Marinescu, Ioana, 2009. "Job Security Legislation and Job Duration: Evidence from the United Kingdom." Journal of Labor Economics 27.3 465-486.

Messina, Julian; and Giovanna Vallanti. 2007. "Job Flow Dynamics and Firing Restrictions: Evidence from Europe.” Economic Journal 117 (June): F279-301.

Micco, Alejandro, and Carmen Pagés. 2006. "The Economic Effects of Employment Protection: Evidence from International Industry-Level Data," IZA DP No. 2433 November.

Miles, Thomas J. 2000. "Common Law Exceptions to Employment at Will and U.S. Labor Markets." Journal of Law Economics \& Organization 16.1 74-101.

Mincer, Jacob. 1976. "Unemployment Effects of Minimum Wages." Journal of Political Economy 84.4 Part 2 (August): S87-S104.

Montenegro, Claudio E., and Carmen Pagés. 2004. "Who Benefits from Labor Market Regulations? Chile, 1960-1998." in Heckman and Pagés. eds., Law and Employment: Lessons from Latin America and the Caribbean Chicago, The University of Chicago 401-434.

Nickell, Stephen, J. 1978. "Employment and Labour Demand over the Cycle." Economica NS 45.180 (November): 329-345.

Nickell, Stephen, and Richard Layard. 1999. "Labor Market Institutions and Economic Performance," in Orley Ashenfelter and David Card, eds., Handbook of Labor Economics 3C Amsterdam: Elsevier: 3029-3084.

OECD. 1999 "Employment Protection and Labour Market Performance." in OECD Employment Outlook Chapter 2 Paris: OECD.

OECD. 2004. "Employment Protection Regulation and Labour Market Performance." in OECD Employment Outlook Chapter 2 Paris: OECD.

OECD. 2006. "Reassessing the Role of Policies and Institutions for Labour Market Performance: A Quantitative Analysis." in OECD Employment Outlook Chapter 7 Paris: OECD. 
Pagés, Carmen, and Claudio E. Montenegro. 2007. "Job Security and the Age-Composition of Employment: Evidence from Chile." Estudios de Economia 34.2: 109-139

Parsons, Donald O. 1986 "The Employment Relationship: Job Attachment, Work Effort, and the Nature of Contracts." in Orley Ashenfelter and Richard Layard, eds. Handbook of Labor Economics North Holland Press 799-949.

Parsons, Donald O. 2005 "Benefit Generosity in Voluntary Severance Plans: The U.S. Experience." mimeo, George Washington University, (December) Available at SSRN: http://ssrn.com/abstract=877903.

Parsons, Donald O. 2011a. "The Firing Cost Implications of Alternative Severance Pay Designs" In Robert Holzmann and Milan Vodopivec, eds., Improving Termination Pay: An International Perspective, Washington, DC: World Bank.

Parsons, Donald O. 2011b "Severance Pay Mandates: Firing Costs, Hiring Costs, and Firm Avoidance Behaviors," mimeo, George Washington University.

Saavedra, Jaime, and Maximo Torero. 2004. "Labor Market Reforms and Their Impact over Formal Labor Demand and Job Market Turnover: The Case of Peru." in Heckman and Pagés, eds., Law and Employment: Lessons from Latin America and the Caribbean Chicago, The University of Chicago: 131-182.

Salanié, Bernard. 2005. The Economics of Contracts: A Primer. Second Edition, MIT Press.

Schivardi, Fabiano, and Roberto Torrini 2008. "Identifying the Effects of Firing Restrictions Through Size-Contingent Differences in Regulation," Labour Economics 15: 482-511.

UNIDO (United Nations Industrial Development Organization. 2002. Industrial Statistics Database.

Vodopivec, Milan. 2004. "Introducing Unemployment Benefits To Sri Lanka," World Bank (HDNSP): Washington, DC July. 
TABLE 1

Expected Cost of Alternative Labor Market Mandates

In Months of Wages OECD AND LAC Sample. Heckman and Pagés (2004)

\begin{tabular}{|l|c|c|c|}
\hline Policy & FULLSAMPLE & $\begin{array}{c}\text { OECD } \\
\text { Only }\end{array}$ & $\begin{array}{c}\text { LAC } \\
\text { Only }\end{array}$ \\
\hline & $(1)$ & $(2)$ & $(3)$ \\
\hline & & & \\
\hline Advance Notice & 0.82 & 0.87 & 0.65 \\
& $(0.48)$ & $(0.48)$ & $(0.45)$ \\
\hline Indemnity For Dismissal & 1.27 & 0.86 & 2.82 \\
(Severance Insurance Pay) & $(1.40)$ & $(1.17)$ & $(1.05)$ \\
\hline Seniority Pay & 0.65 & 0.00 & 3.09 \\
(Severance Savings Pay) & $(2.35)$ & $(0.00)$ & $(4.33)$ \\
\hline Social Security Contrib. & 35.65 & 37.12 & 30.14 \\
& $(19.13)$ & $(20.65)$ & $(10.17)$ \\
\hline
\end{tabular}

Source: Heckman and Pagés (2004, Table 7, p.67). Standard deviations reported in parentheses. 
TABLE 2

The Estimated Impacts Of Alternative Labor Market Mandates (In Months of Wages) On Employment Bevels OECD AND LAC Sample. Heckman and Pagés (2004)

\begin{tabular}{|l|c|c|c|}
\hline Policy & FULLSAMPLE & $\begin{array}{c}\text { OECD } \\
\text { Only }\end{array}$ & $\begin{array}{c}\text { LAC } \\
\text { Only }\end{array}$ \\
\hline & $(1)$ & $(2)$ & $(3)$ \\
\hline & & & \\
\hline Advance Notice & 13.938 & 13.775 & 16.637 \\
& $(15.959)$ & $(14.564)$ & $(15.420)$ \\
\hline Indemnity For Dismissal & 1.161 & $-2.577^{\star \star}$ & 0.330 \\
(Severance Insurance Pay) & $(0.897)$ & $(1.196)$ & $(1.637)$ \\
\hline Seniority Pay & $3.292^{\star \star \star}$ & -- & 1.887 \\
(Severance Savings Pay) & $(1.195)$ & & $(2.197)$ \\
\hline Social Security Contrib. & $-0.230^{\star \star \star}$ & $-0.301^{\star \star \star}$ & $-0.187^{\star \star}$ \\
& $(0.081)$ & $(0.102)$ & $(0.084)$ \\
\hline
\end{tabular}

Source: Heckman and Pagés (2004, Table 8, p.72). Standard errors in parentheses.

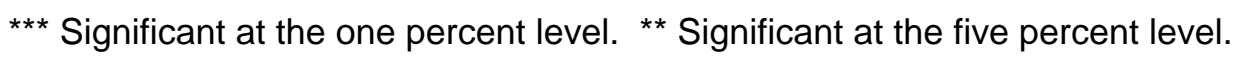




\section{TABLE 3}

OECD Eighteen Point Employment Protection Legislation (EPL) Index OECD (2004)

POLICY

Notification procedures

Delay involved before notice can start

Length of the notice period at:

9 months tenure

4 years tenure

20 years tenure

Severance pay at:

9 months tenure

4 years tenure

20 years tenure

Definition of justified or unfair dismissal

Length of trial period

Compensation following unfair dismissal

Possibility of reinstatement following unfair dismissal

Valid case for use of fixed-term contracts (FTC)

Maximum number of successive FTC

Maximum cumulative duration of successive FTC

Types of work for which temporary work agency (TWA) employment is legal

Restrictions on number of renewals

Maximum cumulated duration of TWA contracts

Definition of collective dismissal

Additional notification requirements

Additional delays involved before notice can start

Other special costs to employers.
INDEX WEIGHT

0.069444

0.069444

0.019841

0.019841

0.019841

0.026455

0.026455

0.026455

0.034722

0.034722

0.034722

0.034722

0.104167

0.052083

0.052083

0.104167

0.052083

0.052083

0.041667

0.041667

0.041667

0.041667

OECD (2004, Table 2.11.1 pp. 103-105) 
FIGURE 1

MANDATED SEVERANCE PAY FOR REDUNDANCY BY OCCUPATION IN WEEKS PAY AT 20 YEARS OF SERVICE OECD COUNTRIES

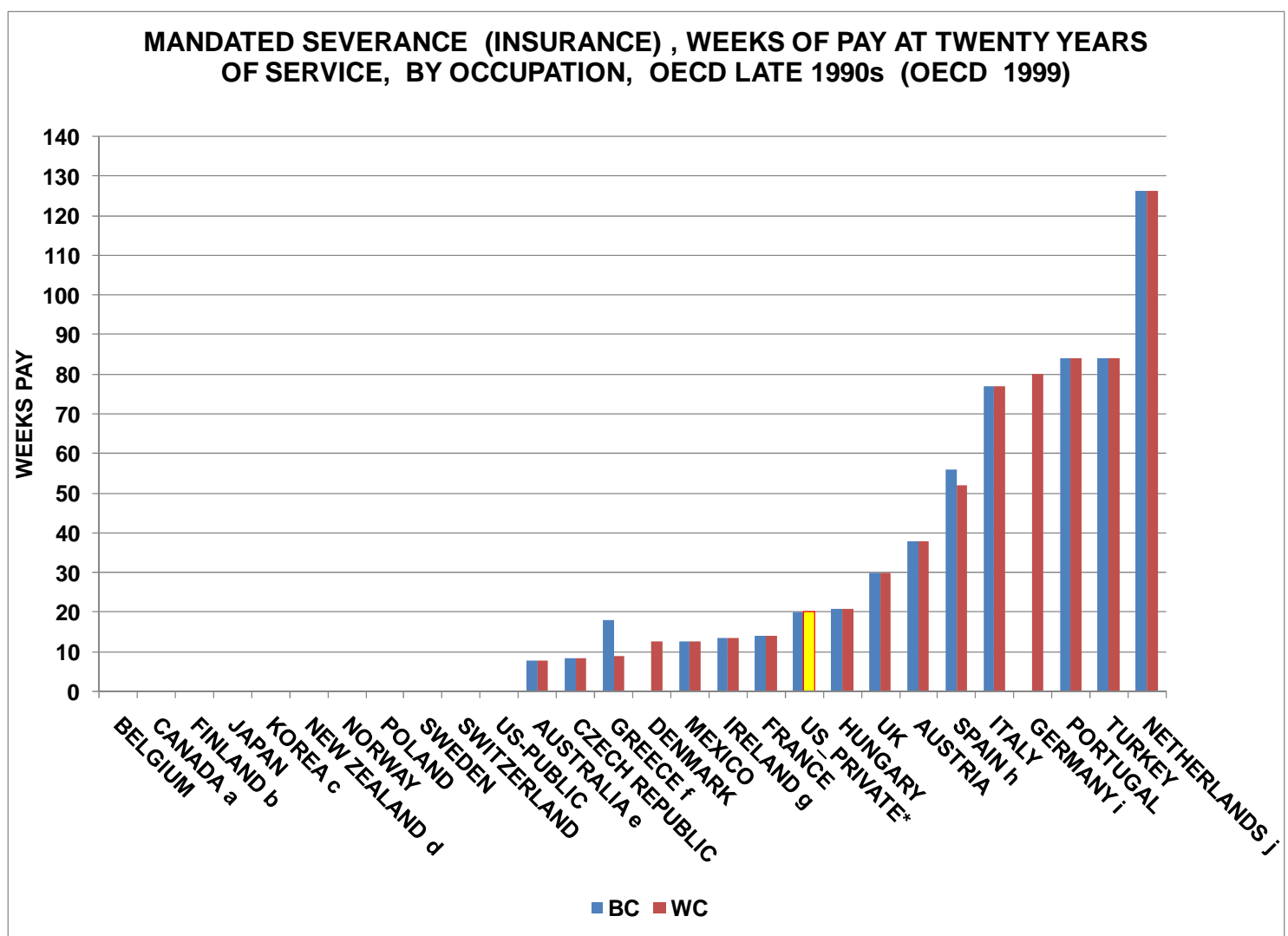

Source: OECD (1999, Table 2.A.2)

a Ontario one week per year of service up to 26 weeks pay if tenure $>5$ and in a firm with payroll of 2.5 million or more.

b Special exceptions for older.

c Retirement allowance not counted.

d Higher collectively bargained rates than typical in U.S.

e Eight weeks if more than four years

$f$ WC doubles if no written notice.

g Employers partially reimbused from redundancy fund.

h Max 12 months or 52 weeks.

i Common in Social Plans adjudicated by the Labour Court

$\mathrm{j}$ If file for permission by a labour court. 
FIGURE 2

\section{Panel A: Regulating Employment Practices}

"RIGIDITY OF EMPLOYMENT INDEX" AND ITS COMPONENTS TOP TEN AND BOTTOM TEN COUNTRIES, COST OF DOING BUSINESS 2009

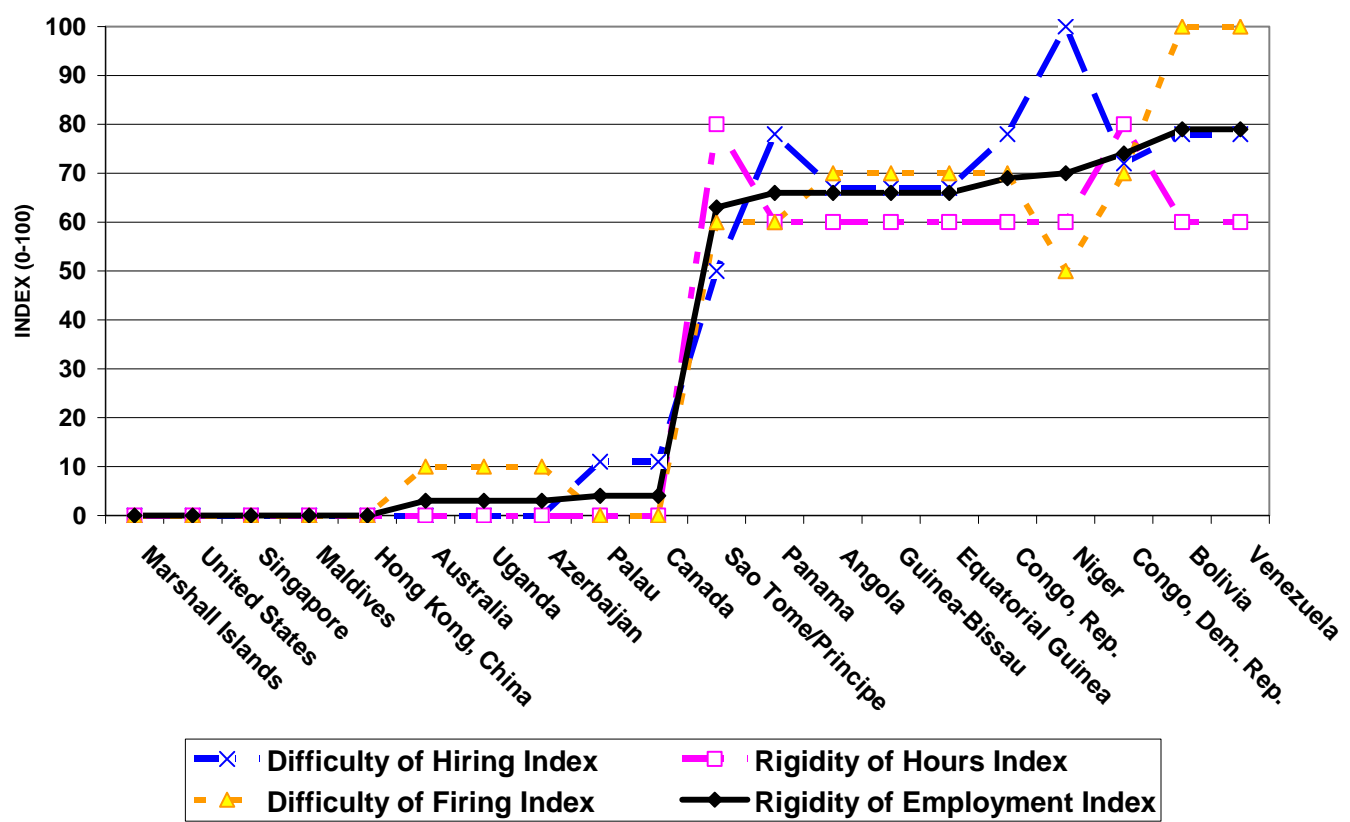

Panel B: Regulating Business Practices

"EASE OF DOING BUSINESS" RANK AND RANK OF COMPONENTS TOP TEN AND BOTTOM TEN OF 182 COUNTRIES, COST OF DOING BUSINESS 2009
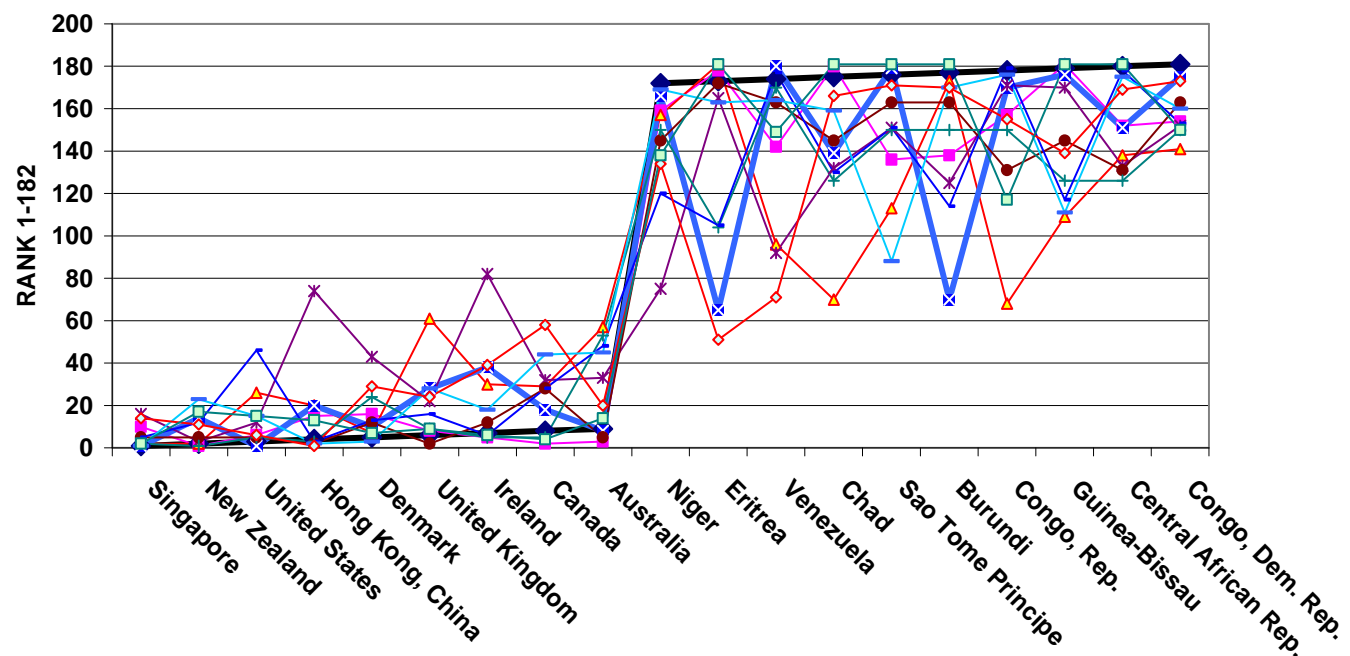

\begin{tabular}{lll|}
$\rightarrow-$ Ease of Doing Business Rank $\rightarrow-$ Starting a Business & - Dealing with Const. Permits \\
$\rightarrow-$ Employing Workers & $\rightarrow$ Registering Property & - Getting Credit \\
$\multimap$ Protecting Investors & - Paying Taxes & - Trading Across Borders \\
$\multimap-$ Enforcing Contracts & $-\square$ Closing a Business & \\
\hline
\end{tabular}


FIGURE 3

PERCENT OF EMPLOYERS WITH GROWTH IN EMPLOYMENT BY REGULATION TYPE AND SIZE OF FIRM ABIDOYE, ORAZEM, AND VODOPIVEC (2009)

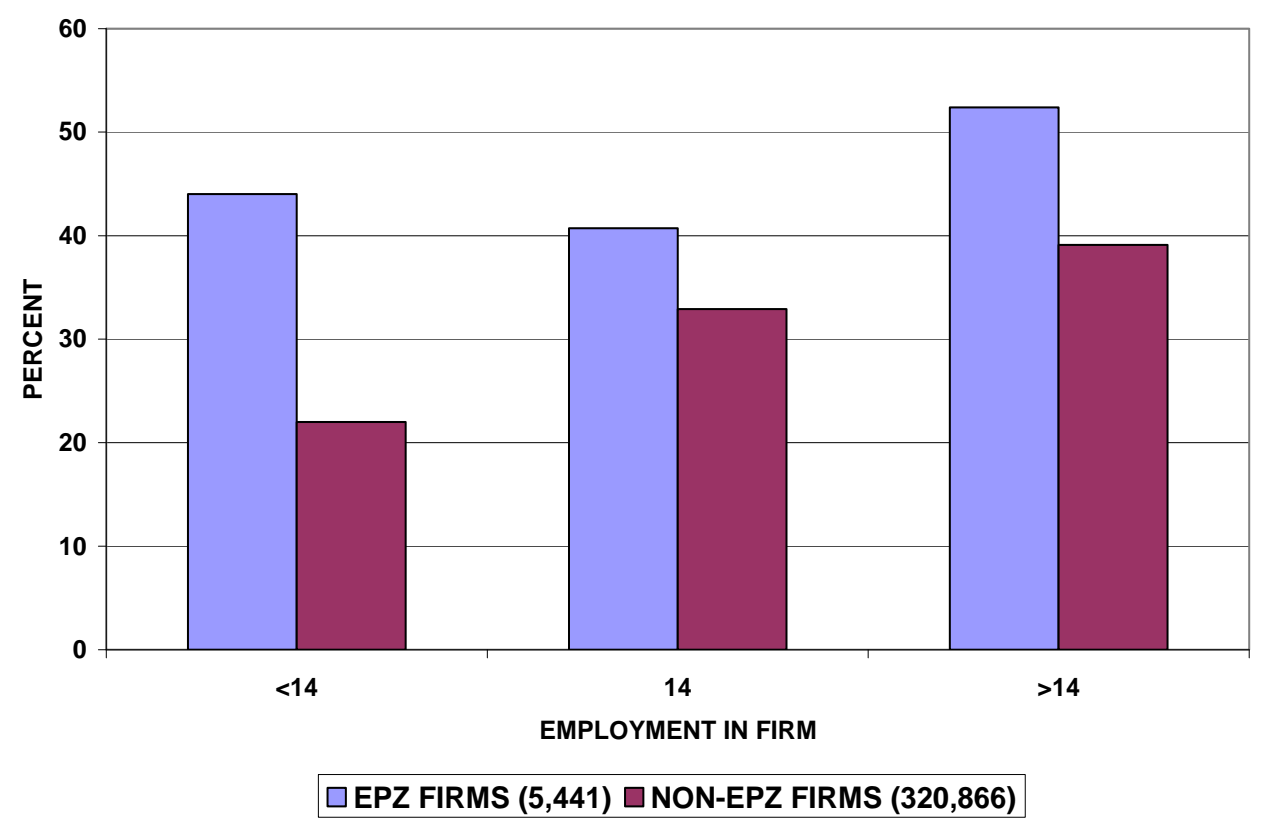

Source: Abidoye, Orazem, and Vodopivec (2009, p.28) 